Cornell Law Library

Scholarship@Cornell Law: A Digital Repository

Cornell Law Faculty Publications

Faculty Scholarship

$1-1-1993$

\title{
Street Harassment and the Informal Ghettoization of Women
}

Cynthia Grant Bowman

Cornell Law School, cgb28@cornell.edu

Follow this and additional works at: http://scholarship.law.cornell.edu/facpub

Part of the Constitutional Law Commons, Law and Society Commons, and the Women Commons

\section{Recommended Citation}

Bowman, Cynthia Grant, "Street Harassment and the Informal Ghettoization of Women" (1993). Cornell Law Faculty Publications. Paper 142.

http://scholarship.law.cornell.edu/facpub/142

This Article is brought to you for free and open access by the Faculty Scholarship at Scholarship@Cornell Law: A Digital Repository. It has been accepted for inclusion in Cornell Law Faculty Publications by an authorized administrator of Scholarship@Cornell Law: A Digital Repository. For more information, please contact jmp8@cornell.edu. 


\title{
HARVARD LAW REVIEW
}

\author{
ARTICLES \\ STREET HARASSMENT AND THE INFORMAL \\ GHETTOIZATION OF WOMEN
}

\author{
Cynthia Grant Bowman*
}

The law often overlooks harms to women. One such harm is the harassment that women face when they travel along city streets and appear in other public places. This street harassment can have profound effects on women's full participation in the public sphere. In this Article, Professor Bowman calls attention to these harms and proposes potential legal remedies for the harassment of women on the public streets. She begins by describing what street harassment involves and whom it affects and then discusses the legally cognizable harms to women and society. Next, she evaluates the criminal and civil laws that might be used to target harassment and describes their failings. Finally, she proposes new methods to stop street harassment and open the public sphere to women. Although Professor Bowman admits that her solutions are not foolproof (and may face severe constitutional attacks), she emphasizes that for the law to recognize the substantial burdens that street harassment places on women's liberty, equality, and sense of self-dignity is a first step toward a solution.

$A$ woman walks down a city street. A man whom she does not know makes an obscene noise or gesture. She counters with a retort or ignores him and walks on. $r$

This is a common enough sequence of events. It happens every day of the year. . . . Superficially, this is a simple, ordinary encounter. ...

But beneath the surface is a complexity of feeling, thought, and intention that, despite two decades of feminist theorizing and two millennia of women writing about women, we have just begun to decode. Hidden in this complexity are the personal and political

\footnotetext{
* Associate Professor of Law, Northwestern University School of Law. For their helpful comments on early drafts of this Article, I thank Mary Becker, Locke Bowman, Bernardine Dohrn, Leonard Rubinowitz, Morrison Torrey, and the members of the Chicago Feminist Law Teachers Colloquium. I am grateful also for the research assistance of Genevieve Daniels, Victoria Hinson, Sara Love, and Lyn Schollett. This Article is dedicated to the memory of my colleague Jim Haddad, a gentle man and good friend.
} 
contradictions of women's lives, making the experience of street hassling the quintessential moment of femininity in our culture.

Muriel Dimen, Surviving Sexual Contradictions ${ }^{1}$

\begin{abstract}
A recurrent theme of feminist jurisprudence is that the law fails to Atake seriously events which affect women's lives. The law trivializes or simply ignores events that have a profound effect upon women's consciousness, physical well-being, and freedom. Until relatively recently, for example, no term even existed to describe what is now universally called "sexual harassment," although the phenomenon itself was well known to women. ${ }^{2}$ Yet, within the brief period since the naming and describing of this phenomenon, the concept has entered the law as a form of sex discrimination forbidden under Title VII of the Civil Rights Act of $1964 .{ }^{3}$ The development of this legal concept and its embodiment in theories of liability has significantly affected popular understanding of acceptable modes of interaction in the workplace. ${ }^{4}$ Thus, as Catharine MacKinnon has described, "the legal concept of sexual harassment reenters the society to participate
\end{abstract}

1 Muriel Dimen, Surviving Sexual Contradictions: A Startling and Different Look at a Day in the Life of a Contemporary Professional Woman 3-4 (1986).

2 Lin Farley apparently coined the term "sexual harassment" in the mid-r97os. See LIN Farley, Sexual Shakedown: The Sexual Harassment of Women on the Job at xi (1978); see also Barbara A. Gutek, Sex AND the WorkPlace 5-6 (1985) (describing Farley's work as "[t]he first large-scale, systematic analysis" of sexual harassment). But see CathaRINE A. Mackinnon, Sexual Harassment of Working Women: a CaSe of Sex DiscriminaTION 250 n.13 (1979) (stating that Working Women United Institute was "the first to use these words as anything approaching a term of art").

${ }^{3} 42$ U.S.C. $\$ \S 2000$ e to $2000 e-17$ ( 1988 ). Sexual harassment has been defined as:

Unwelcome sexual advances, requests for sexual favors, and other verbal or physical conduct of a sexual nature [that] (I) . . . is made either explicitly or implicitly a term or condition of an individual's employment, (2) ... is used as the basis for employment decisions affecting such individual, or (3) . . has the purpose or effect of unreasonably interfering with an individual's work performance or creating an intimidating, hostile, or offensive working environment.

29 C.F.R. $\S$ I604.II(a) (I99I); see Meritor Sav. Bank v. Vinson, 477 U.S. 57, 64-65 (1986).

${ }^{4}$ During the past decade, employer concerns about potential third-party liability for sexual harassment claims against their agents have led to a great deal of literature, publicity, and internal education about this issue. See, e.g., Cheris Kramarae, Harassment and Everyday Life, in Women Making Meaning: New Feminist Directions in Communications Research roo (Lana Rakow ed., 1992). Possibly as a result of this attention, both men and women are now more likely to "know it when they see it." See, e.g., Sexual Harassment in Your Office: The Working Women Survey, Working WOMEN, Feb. 1992, at 14, 14-16. The televised confirmation hearings of Supreme Court Justice Clarence Thomas in I99I, which focussed for four widely-viewed days on the testimony of his former employee, law professor Anita Hill, that Thomas harassed her in the workplace, appear to have publicized the legal concept of sexual harassment to a much wider audience as well. 
in shaping the social definitions of what may be resisted or complained about, said aloud, or even felt." 5

This Article examines another type of sexual harassment that profoundly affects women's lives: the harassment of women in public places by men who are strangers to them, ${ }^{6}$ which I call "street harassment." 7 Street harassment is a phenomenon that has not generally been viewed by academics, judges, or legislators as a problem requiring legal redress, either because these mostly male observers have not noticed the behavior ${ }^{8}$ or because they have considered it trivial and thus not within the proper scope of the law. ${ }^{9}$ In Part I, therefore, I describe the very real harms of this widespread social phenomenon. I focus upon its effects and show how women experience street harassment - how being subjected to this intrusion feels from a woman's point of view - and the consequences it has on our lives. ${ }^{10}$ In

\footnotetext{
5 MACKINNON, supra note 2, at 57.

${ }^{6}$ For a more detailed definition and description of the types of conduct involved, see pp. 52324 below.

7 I have chosen "street harassment" over "street remarks," "sexual harassment in public places," or other possibilities for a number of reasons: first, to tie the phenomenon to conduct that is now punishable as harassment in the workplace; second, to emphasize the conduct component over the speech component for First Amendment purposes; and third, to emphasize that this conduct is not essentially sexual in nature as much as it is motivated by, and instrumental to, male power and hierarchy. Although the street is in fact one very common venue, I use the word "street" here simply as an abbreviation for any public place; this type of harassment takes place in many other venues, such as buses, trains, taxis, bus stations, and the like. For a discussion of terminology referring to street harassment, see Elizabeth A. Kissling, Street Harassment: The Language of Sexual Terrorism, 2 Discourse \& Soc'y 45x, 456-57 (I9g1).

8 Delores Hayden, professor of architecture and urban planning at UCLA, has identified this lack of perception as one of the damaging effects of the differential access of men and women to public space:

"Sometimes men do not really understand the difficulties that face employed women who are traversing the city alone because when women are with men, they are much more likely to be free from verbal harassment on the streets and to be free from gratuitous attacks. When they are alone, in fact, there is a tremendous amount of hostility that just comes off the sidewalks of the city."
}

Cheris Kramarae, Speech Crimes Which the Law Cannot Reach, or Compliments and Other Insulting Behavior, in ProceEdings of THE FIRST BERKELEY WOMEN AND LANGUAGE CoNFERENCE 84, 93 (Sue Bremner, Noelle Caskey \& Birch Moonwomon eds., I985) (quoting Delores Hayden).

${ }^{9}$ Robin West suggests that the law does not recognize gender-specific injuries like street harassment because the legal culture fails to understand the different quality of women's subjective, hedonic lives in general, not simply because the legal culture does not perceive these injuries or views them as unimportant. See Robin L. West, The Difference in Women's Hedonic Lives: A Phenomenological Critique of Feminist Legal Theory, 3 WIs. Women's L.J. 81, 8385 (1987).

10 I offer this as a modest example of what Mari Matsuda calls "outsider jurisprudence," a methodology that is "grounded in the particulars of [the] social reality and experience" of nondominant groups and that attempts to "know history from the bottom." Mari J. Matsuda, Public Response to Racist Speech: Considering the Victim's Story, 87 Mich. L. Rev. 2320, 2323-26 (I989). 
Part II, I recast these harms into categories recognized by the law. In Part III, I examine a variety of concepts that current law might use to combat conduct of this sort, including assault, intentional infliction of emotional distress, invasion of privacy and the tort of intrusion, as well as the many statutes already on the books that prohibit intimidation or harassment and the use of abusive language on the streets. I then show how these legal categories, as they have been interpreted so far, have not in fact addressed the harms of street harassment.

From a feminist perspective, it is not surprising that existing legal concepts, fashioned primarily by male judges and legislators in light of the experiences encountered by men, fail to provide effective remedies for the peculiarly female-directed experience of street harassment. Nonetheless, this failure fundamentally contradicts the values underlying Anglo-American law, for the legal remedies available to women in this context are inadequate to secure even the most primary goods of a liberal democratic society. "[L]iberty," as John Locke observed, "is to be free from restraint and violence from others; which cannot be where there is no law . . .."11 The liberty of women, in this most fundamental sense of freedom from restraint, is substantially limited by street harassment, which reduces their physical and geographical mobility and often prevents them from appearing alone in public places. ${ }^{12}$ In this sense, street harassment accomplishes an informal ghettoization of women - a ghettoization to the private sphere of hearth and home.

The most fundamental definitions of liberty include the right of an individual to go where she chooses in spaces that are public. ${ }^{13}$ Indeed, liberty of this sort is essential to equal participation in the affairs of the polis. ${ }^{14}$ The security to move about in public, what Blackstone

11 John LOCKe, The Second Treatise of Government, in THE SECOND TREATISE of GovERnMent AND a LetTer Concerning Toleration 3, ch. VI, $\$ 57$, at 29 (J.W. Gough ed., corrected \& rev. ed. 1956) (3d ed. I698); see also MoNTESQUIEU, THE SPIRIT OF THE LAws pt. 2, bk. II, ch. 6, at I57 (Anne M. Cohler, Basia C. Miller \& Harold S. Stone trans. \& eds., I989) (I748) ("Political liberty in a citizen is that tranquillity of spirit which comes from the opinion each one has of his security ...."); id. pt. 2, bk. 12, ch. 2, at 888 ("Political liberty consists in security or, at least, in the opinion that one has of one's security.").

12 See infra pp. 539, 541-42.

13 Benard and Schlaffer preface their report on harassment with a particularly apt quotation from Hegel:

"It is a violation of my natural external freedom, not to be able to go where I please. . . My personality is wounded by such experiences, because my most immediate identity rests in my body."

Cheryl Benard \& Edit Schlaffer, The Man in the Street: Why He Harasses, in FEmInisT Frameworks: Alternative Theoretical Accounts of the Relations BetweEN WoMen AND MEN 70, 70 (Alison M. Jaggar \& Paula S. Rothenberg eds., 2d ed. 1984) (quoting G.W.F. Hegel, Texte Zur Philosophischen Propaedeutik (1840)).

${ }^{14}$ According to Aristotle, the inability to share in the life of the polis indicates that an individual is something less than human. ARIstotre, Politics bk. I, ch. 2, § 14 (Ernest 
called "the power of locomotion,"15 is one of the most basic civil rights; it is essential to the rights to assemble and petition for redress of grievances - the primary prerequisites to participation in public affairs and admission to the public realm. ${ }^{16}$ Thus, when the law fails to protect women from street harassment, it deprives them of one of the basic goods for which government was ordained, leaving them in an Hobbesian wilderness men do not share. ${ }^{17}$

In order to participate as equal citizens in the polis, women must reclaim the public space. Hence, my inquiry does not end simply with an analysis of the law's current inadequacy in addressing the harms of street harassment. We must either fashion new legal concepts equal to this task or reformulate existing legal categories to make them apply to the experience of street harassment. This is one of the goals of what Robin West has called "reconstructive feminist jurisprudence": to "reconstruct the reforms necessary to the safety and improvement of women's lives in direct language that is true to our own experience

Barker trans., 1962) ("The man who is isolated - who is unable to share in the benefits of political association or has no need to share because he is already self-sufficient - is no part of the polis, and must therefore be either a beast or a god."). The importance of access to the public sphere is also an important theme in modern liberal thought. See, e.g., HaNNArH ARENDT, ON REVOLUTION II5-27 (I963) [hereinafter ARENDT, ON REvolution]. Arendt described the virtue of political life as follows: "the joy and the gratification that arise out of being in company with our peers, out of acting together and appearing in public, out of inserting ourselves into the world by word and deed, thus acquiring and sustaining our personal identity and beginning something entirely new." HANNAH ARENDT, BETWEen PAST AND FUTURE 263 (Penguin Books r977) (196r).

15 I William Blackstone, Commentaries *izo.

16 See ARENDT, ON Revolution, supra note 14 , at $24-25$. If it is not intuitively obvious why the freedom to move about in public is essential to any meaningful access to the public sphere, a personal anecdote may help. When I was a graduate student in the mid- to late I960s, I lived in New York City. It was a time of intense political activity in the United States, especially for people my age and at my university (Columbia). I became very interested in the antiwar movement, in the struggle against apartheid in South Africa and the then-Portuguese colonies, and, ultimately, in the incipient women's liberation movement. But I lived in a city where the work day began and ended late; political meetings invariably took place in the evenings, and I felt unsafe as a woman on the streets. Unless I could find a male escort, I was reluctant to go out after 5 or 6 p.m.; thus, I spent most of my years in New York reading in the isolation of my home. When I moved to Chicago in the early I970s, however, I owned a car and could find parking relatively close to any destination. Although gender relations were no different in Chicago, and the streets were not conspicuously safer for women, I suddenly felt safe and thus free to attend meetings and to become politically involved. These activities proved central to the formation of my perspective on the world and, ultimately, to the identification of my own position, politically, within this nation. For me, therefore, there is an intimate connection between the simple freedom to move about in public and the capacity to participate in the political process. I understand Blackstone's and Arendt's association of the power of locomotion and access to the political sphere in this way.

17 The reference, of course, is to Hobbes's image of a state of nature prior to the establishment of a sovereign who would prevent the "war of every one against every one" by the use of coercive force. Thomas Hobbes, Leviathan pt. I, ch. 13, at too (Michael Oakeshott ed., Collier Books I962) (r65I). 
and our own subjective lives."18 Therefore, in Part IV of this Article I propose a variety of ways in which we can use or reform the law to address street harassment. However, these potential legal remedies will only enter the law if women - as plaintiffs and as lawyers determine collectively to adopt them.

\section{Street Harassment: What It Looks Like FROM A FEMINIST PROSPECTIVE}

The literature of law and social science is largely silent about the harassment of women in public places. The legal academy has not viewed street harassment as an issue worthy of attention, despite Robin West's repeated depiction of it as a disempowering injury to women that is virtually unrecognized by the law:

[W]omen suffer unpunished and uncompensated sexual assaults continually. Women who live in urban areas and walk rather than drive or take taxis endure tortious or criminal sexual assaults daily. Although we have a trivializing phrase for these encounters - "street hassling" - these assaults are not at all trivial. They are frightening and threatening whispered messages of power and subjection. They are, in short, assaults. Yet, men who harass women on the street are not apprehended, they are not punished, the victims are not compensated, and no damages are paid. The entire transaction is entirely invisible to the state. ${ }^{19}$

With the exception of one sociological discussion written in English ${ }^{20}$ and one survey by two Austrian sociologists, ${ }^{21}$ the study of street harassment has been carried out by a handful of scholars in the fields of speech, language, and communication. ${ }^{22}$ In the face of this relative silence, any student of street harassment must supplement the academic literature with sources less typical of legal scholarship - popular magazines directed at female audiences, literature, movies, plays, and letters to the editor in large city newspapers - in which women

18 Robin West, Jurisprudence and Gender, 55 U. CHr. L. REV. I, 70 (1988).

19 Robin West, Pornography as a Legal Text, in For Adult Users OnLy: The Dilemma of Violent PoRnography I08, in (Susan Gubar \& Joan Hoff eds., 1989); cf. West, supra note 9, at 106-08 (describing the fear associated with street harassment and the consequent "giving away for visual consumption [women's] sexual appearance").

20 See Carol B. Gardner, Passing By: Street Remarks, Address Rights, and the Urban Female, 50 Soc. INQUIRY 328 (1980).

${ }^{21}$ See Benard \& Schlaffer, supra note 13 , at 70-72 (describing the authors' study, which was published only in German).

22 See, e.g., Cheris Kramarae, Women and Men Speaking (I981); Elizabeth A. Kissling \& Cheris Kramarae, Stranger Compliments: The Interpretation of Street Remarks, I4 WoMEN's Studies IN Communication 75 (1991); Kissling, supra note 7; Kramarae, supra note 4; Kramarae, supra note 8; Elizabeth Kissling, Interpreting Street Remarks (Oct. 13, 1986) (unpublished manuscript, on file at the Harvard Law School Library). 
have related their experiences with street harassment. ${ }^{23}$ From these studies and stories, it is possible to construct an account of the harms of street harassment by describing the impact it has on its individual targets ${ }^{24}$ and to assess the impact of street harassment upon women as a group, upon relations between the sexes, and upon society as a whole.

\section{A. Toward a Working Definition of Street Harassment}

A wide variety of behavior is included within the conduct generally considered by targets, survey respondents, and commentators to constitute street harassment. ${ }^{25}$ It includes both verbal and nonverbal behavior, such as "wolf-whistles, leers, winks, grabs, pinches, catcalls and street remarks"; the remarks are frequently sexual in nature and comment evaluatively on a woman's physical appearance or on her presence in public. ${ }^{26}$ The comments range from "Hello, baby" to vulgar suggestions and outright threats, ${ }^{27}$ such as "fucking bitch, fucking cunt,"28 "[w]hite whore,"29 or "you're just a piece of meat to me, bitch."30 Although street harassment encompasses a wide variety of behaviors, gestures, and comments, it has some defining characteristics: (I) the targets of street harassment are female; 31 (2) the harassers are male; (3) the harassers are unacquainted with their targets; (4) the encounter is face to face; (5) the forum is a public one, such as a

23 Catharine MacKinnon notes that "[s]cholars who look down upon such popular journalistic forays into policy research (especially by 'women's magazines') should ask themselves why Redbook noticed sexual harassment before they did." MAcKrnnon, supra note 2, at 248 n.I.

24 I have chosen to use the word "target" rather than "victim" both to avoid the perennial image of woman as victim and also to reflect the military, hunting, and sporting imagery in male literature. See, e.g., Gardner, supra note 20, at 354 n.I8 (describing sporting and recreational images of street harassment in literature written by men). "Target" was also graphically used by one of the women who told her story: "Gradually, I began to understand that the streets were a battle zone, and each woman was a target." Gwenda Blair, Street Hassling: Putting Up with Put Downs, Mademoiselle, July I984, at II8, IIg.

25 In their study of entries in a computer file commenting on street harassment, Kissling and Kramarae concluded that there was remarkable agreement about what constituted street remarks. Women identified as part of the same phenomenon the expressions " $\mathrm{Hey}$, pretty,' 'Hey, whore,' 'What ya doin' tonight?' 'Look at them legs,' 'Wanna fuck?' 'Give me a smile,' and a pinch or rub." Kissling \& Kramarae, supra note 22, at 78.

${ }^{26} \mathrm{Id}$. at $75-76$; see also Gardner, supra note 20 , at 333 (describing the evaluative nature of remarks men make about women on the street).

${ }^{27}$ See, e.g., Carol Dana, Talking Back to Street Harassers, WASH. Post, Aug. 19, 1986, at $\mathrm{C}_{5}$.

28 See Branda v. Sanford, 637 P.2d I223, 1224 (Nev. I98I) (The court's transcription reads: "'f-k-g bitch', 'f-k-g c-t.").

29 Blair, supra note 24 , at Ix 9 .

30 Andrea Kannapell, She Could Have Been Me: 28 and White, Village Vorce, May 9, I 989 , at 37 .

31 The harassment of gay men on the street - "gay bashing" - grounded as it is in homophobia, should be the subject of a separate discussion. 
street, sidewalk, bus, bus station, taxi, or other place to which the public generally has access; 32 but (6) the content of the speech, if any, is not intended as public discourse. ${ }^{33}$ Rather, the remarks are aimed at the individual (although the harasser may intend that they be overheard by comrades or passers-by), ${ }^{34}$ and they are objectively degrading, objectifying, humiliating, and frequently threatening in nature.

Anthropologist Micaela di Leonardo has offered the best working definition of street harassment:

Street harassment occurs when one or more strange men accost one or more women . . . in a public place which is not the woman's/ women's worksite. Through looks, words, or gestures the man asserts his right to intrude on the woman's attention, defining her as a sexual object, and forcing her to interact with him. ${ }^{35}$

Although I will attempt to improve upon this definition by making it more specific and in some ways narrower when I define street harassment as a legal term, ${ }^{36}$ di Leonardo's definition is excellent for its descriptive value. It offers an objective rather than subjective standard by which to define street harassment; it focusses upon the harasser's actions rather than upon his intentions or perceptions; and it captures the experience of street harassment as intrusion.

One must turn to first-person accounts and to literature to get a sense of the experience of street harassment. The following description appeared in Mademoiselle magazine in 1984. It recounts the experiences of a woman who had been inclined as a girl to regard remarks from strange men or boys on the streets as complimentary:

32 Erving Goffman describes "public places" as "any regions in a community freely accessible to members of that community." Erving Goffman, Behavior in PUblic Places 9 (1963).

33 "Public discourse" has been defined by Robert Post as "the communicative processes necessary for the formation of public opinion, whether or not that opinion is directed toward specific government personnel, decisions, or policies." Robert C. Post, Racist Speech, Democracy, and the First Amendment, 32 WM. \& MARY L. REv. 267, 288 (r9gI). Post distinguishes between public discourse and group-based insults directed at individuals outside the context of a political discussion or debate. See id. at 302; see also Robert C. Post, The Constitutional Concept of Public Discourse: Outrageous Opinion, Democratic Deliberation, and Hustler Magazine v. Falwell, I03 HARv. L. REV. 601, 667 (1990) (explaining that the Court has endeavored to define public discourse by distinguishing matters of public and purely private concern).

34 As Elizabeth Kissling points out, it is unclear who is the addressee of street remarks: the woman, male comrades, passers-by, or some combination of the three. Kissling, supra note 22, at $\mathrm{r} 3$.

35 Micaela di Leonardo, Political Economy of Street Harassment, AEgis, Summer 198x, at 5I, 5I-52. Two British authors suggest a much broader definition of harassment, as both unwanted sexual advances and any unsought intrusions by men "into women's feelings, thoughts, behaviours, space, time, energies and bodies." Sue Wise \& Liz Stanley, Georgie Porgie: SEXUAL HARASSMENT IN EVERYDAY LIFE $7 \mathrm{I}$ (1987).

36 See infra pp. $575-76$. 
The shift in [my] thinking started when I moved to Manhattan and discovered that the relatively innocuous "Hey, good-looking" of my suburban girlhood was the exception rather than the rule. For the most part, men simply approached me with crude propositions. The first time a man walked toward me, opened his mouth, began panting and jerked his crotch, I didn't feel the least bit affirmed or desirable. I did feel embarrassed, humiliated, furious - and helpless. - . . It made me feel vulnerable and defenseless, as if I didn't really have control over my own flesh. ${ }^{37}$

Another woman reported the following interchange, which occurred when she was out walking, absorbed in serious thought, and passed two men on the sidewalk:

"Hey, why so serious, honey? Give us a little smile." My sense of humor, he didn't know, was temporarily out of service, so of course I didn't give him a little smile. But in not smiling, I had again violated the code, provoking another seizure of silent suffering that became verbal. As I passed the sleeve on the street, it hissed a word at me, with the edge of anger to it, with a sharp rebuke in it: "Bitch."38

This account describes a common pattern, in which the target's failure to respond results in escalation and a superficially friendly interaction is transformed into one that is transparently hostile. ${ }^{39}$

Finally, an example from a novel by Joyce Carol Oates:

False facts.

The detour around the construction, the mud, the planks, Elena walking carefully on one of the planks, and one of the men yelling at her. Cupping his hands to his mouth, yelling. Another man laughing. Another man laughing. Another man, stocky in his workclothes, throwing something at her that hadn't enough weight to carry itself to her - just a crumpled-up paper bag, a lunch bag.

False facts: they didn't really want to hurt her.

Didn't hate her.

Didn't want her dead.

False facts: the recitation of the weather around the country, the temperature recorded at all the airports. You believe it must mean something but it will not.

False facts: blood on instruments, no proof of pain. Proof only of blood. 40

\footnotetext{
${ }^{37}$ Blair, supra note 24 , at rrg.

38 Mary K. Blakely, True or False: "All Men Like to Girl-Watch, and Girls Don't Mind It", VoGUE, Jan. I982, at 56, 58.

${ }^{39} \mathrm{Cf}$. Kissling, supra note 22, at 9-10 (pointing to the example of a woman who voices her objection and is met with hostility).

40 Joyce Carol Oates, Do with Me What You Will 146-47 (1973), quoted in Gardner, supra note 20 , at 328 .
} 
One cannot help but note the thinly concealed violence underlying each of these encounters.

The interactions described above also reflect major deviations from what sociologists refer to as the norm of civil inattention among strangers in public places. ${ }^{41}$ Typically, unacquainted persons passing on a public street, particularly in large cities, do not address one another, but instead perform an avoidance ritual: they make eye contact briefly from a distance of eight to ten feet, then avert their eyes and raise them again with a mid-distance focus on a point to the side of the passerby. ${ }^{42}$ Staring at a stranger is a well-established cultural taboo. Indeed, Erving Goffman noted, "[t]he act of staring is a thing which one does not ordinarily do to another human being; it seems to put the object stared at in a class apart. One does not talk to a monkey in a zoo, or to a freak in a sideshow - one only stares." "43

Breaches of civil inattention that include a spoken component typically occur only when one encounters a person who is either very unusual (such as an individual carrying a couch, hopping on one foot, or dressed in costume) or unusually similar to oneself in some respect (for example, someone wearing the same college sweatshirt or driving the same make of car), or who is accompanied by someone or something in an "open" category, such as dogs or children. ${ }^{44}$ Men seem to regard women generally as such "open persons." Unlike men, women passing through public areas are subject to "markers of passage" that imply either that women are acting out of role simply by their presence in public or that a part of their role is in fact to be open to the public. ${ }^{45}$ These "markers" emphasize that women, unlike men, belong in the private sphere, the sphere of domestic rather than public responsibility. ${ }^{46}$ Ironically, men convey this message by intruding upon a woman's privacy as she enters the public sphere.

Central to the freedom to be at ease in public spaces is the capacity to pass through them while retaining a certain zone of privacy and autonomy - a zone of interpersonal distance that is crossed only by mutual consent. If, by contrast, women are subject to violation of

41 See Gardner, supra note 20, at 328-34.

42 See id. at 329.

43 GoffmaN, supra note 32 , at 86 (quoting Ralph $\mathrm{K}$. White, Beatrice A. Wright \& Tamara Dembo, Studies in Adjustment to Visible Injuries: Evaluation of Curiosity by the Injured, 43 J. ABNORMAL \& SOC. PSYCHOL. I3, 22 (1948)).

44 See Gardner, supra note 20, at 33I-33.

45 See id. at 333.

46 There is some indication that women are subjected to harassment less frequently when they go to places associated with their domestic responsibilities, such as grocery stores, and are either pregnant or accompanied by a child, which is apparently perceived as a sign that they are some man's "property." See infra p. 530. Of course, men who would harass women may also be less likely to be found at these places. 
that zone of personal privacy when they enter public areas, that very invasion of privacy effectively drives women back into the private sphere, where they may avoid such violations. Thus, by turning women into objects of public attention when they are in public, harassers drive home the message that women belong only in the world of the private.

\section{B. Is Street Harassment a New Phenomenon?}

Rare but occasional mention in the case law demonstrates that the harassment of women in public places predates the modern period. ${ }^{47}$ One particularly graphic account appears in the report of an 1875 suit for damages brought by a twenty-year-old schoolteacher against the Chicago \& Northwestern Railroad for the unseemly behavior of its conductor:

The conductor then came and sat down near the plaintiff . . . "He said, 'I suppose you are married like all the rest of the school marms?' I said, 'No, I am not.' Then he sat up nearer to me, and put his hand in my muff, and said, 'There is room for two hands in this muff, aint there?' I said, 'No, sir, there is not for yours,' and jerked my muff away. . . . I had the tassel of my muff in my hand, tossing it, and he said, 'If you don't stop twisting that, you will wear it all out.' I said, 'I don't care if I do.' He then said, 'What makes you look so cross?' I didn't answer him, but turned away from him. Pretty soon he got up, and I supposed he was going away. He stepped to the side of my chair, threw his arms around me, and held my arms down. He threw his left arm around my shoulder, and took hold of my arm between the shoulder and left elbow with his right arm; he pressed his elbow on my right arm, and then commenced kissing me. I said, 'Oh, let me go; you will kill me.' He said, 'I am not agoing to hurt you.' Then I said, 'Do let me go; I will jump out of the car, if you will.' I tried to get up on my feet, and he pushed me back in the chair, and said, 'I aint agoing to hurt you.' Then I said, 'What have I ever done to you, that you should treat me in this way?' After

${ }^{47}$ Cheris Kramarae located one poignant plea in an 1898 letter to a British journal:

A matter of great importance to all women, and one which $I$ have never known to be publicly discussed, is the grave annoyance to which women - and particularly young girls - are subjected, by being followed and spoken to by men when walking through the streets alone. The men do not necessarily belong to the class of tramps and loafers, but, on the contrary, are often well dressed and seemingly respectable. . . . It is sad to think that even at the present day a woman cannot go out and return to her home without the fear of being molested. But since the innate chivalry which one pre-supposes in every man has not hitherto sufficed to secure unprotected women from impertinent vexation of the kind described, it seems to me highly necessary to discuss the subject from all sides, and to find if possible both a preventative and a remedy for the evil.

Womanhood, Dec. 1898, quoted in Kramarae, supra note 4, at Ir2. 
he had kissed me five or six times, he said, 'Look me in the eye, and tell me if you are mad.' I said, 'Yes, I am mad."'48

Many women reading this account in the Iggos would likely react to it with an empathetic identification drawn from similar experiences of sexual harassment. Although this encounter resulted in an outright assault - indeed, a battery - the imposition of unwanted attention of a type leading to assault is familiar to female passengers on buses and subway trains today. ${ }^{49}$ For this reason, the story sounds remarkably modern.

With the advent of the "Second Wave" of the women's movement in the I970s and I980s, personal accounts of street harassment began to appear in popular journals with some frequency. Harassment may also have become more offensive and frequent in these two decades. ${ }^{50}$ The increase in harassment seems attributable, at least in part, to the many changes in women's lives during this period, including their entry into the workforce in record numbers, the rise both in the age of first marriage and in the divorce rate, the delay of childbirth on the part of working women, public acceptance of unchaperoned women; and the outdoor nature of the physical fitness movement. 51 All of these changes increased the likelihood that women would be present in public areas and would be there unaccompanied by children or male escorts. ${ }^{52}$ Periods of recession and unemployment also seem to be associated with increases in the incidence of street harassment - by literally placing men on the streets in many neighborhoods. In the opinion of some, a more general deterioration in public civility has also exacerbated the problem. ${ }^{53}$ Thus, what may well be an ageold institution has become a particularly virulent and widespread practice in modern American cities.

48 Craker v. Chicago \& N.W. Ry., 36 Wis. 657,659 (1875). The conductor was convicted of assault. See id. at 674 . The plaintiff's suit for damages against the railroad also succeeded. See id. at 679 ; infra p. 566 .

49 See infra note 258.

50 See di Leonardo, supra note 35 , at 53.

51 See id. at 53-54.

52 See id. at 54. The flip side of these changes, as di Leonardo points out, is that, for the first time, men are more likely to have competition from women in the workplace and less likely to have the same quality of services in the home because of the absence of a full-time homemaker - or, indeed, to receive the same deference and psychological rewards to which many may have been accustomed before the women's movement. See id. Changes in men's lives may also account, at least in part, for the increase in harassing conduct over this period. Indeed, this increase may be one aspect of the more general "backlash" phenomenon described by Susan Faludi in her ig9i best seller. See SuSAN Faludi, Backlash: The UNdeclared War AgaINST AMERICAN WoMEN at xviii-xxiii (I99I).

53 See di Leonardo, supra note 35, at 54; Cristina Del Sesto, Our Mean Streets: D.C.'s Women Walk Through Verbal Combat Zones, WASH. Post, Mar. 18, 1990, at B1. The problem may be exacerbated by the increased acceptability in common usage of words previously considered obscene. 


\section{The Geography of Street Harassment}

Street harassment is a common occurrence in large urban areas. News articles and commentators report that street harassment is particularly frequent, intense, and sexually explicit in Washington, D.C. ${ }^{54}$ Street harassment occurs both in the South of the United States and in the North. Florence King described her encounter with some "Good Ole Boys," whom she described as a "Southern Wasp phenomenon" with a facility for double entendre:

Benches always draw the Good Ole Boys; any long seating arrangement in the South is bound to be full of them. Courthouse railings are their favorite hangout but a row of anything will do.

As I walked past them [in a bus station waiting room] it began.

"Shore would like to have that swing in my backyard."

"You want me to help you with your box, li'l lady?"

"Hesh up, Alvin, that ain't nice. Don't you talk to her like that."

"I just want to help her with her box, thass all."

Indeed, street harassment is a worldwide phenomenon, 56 apparently absent only in small villages and under fundamentalist regimes in which women are literally veiled and seldom seen in public. ${ }^{57}$ One graduate student from India told me, for example, that, in the more than one year during which she worked as a lawyer in New Delhi, she was harassed at least once every day; she attributed this harassment to the fact that she was wearing Western clothes and engaging in non-traditional pursuits. Newspaper reports support her account of the pervasiveness of this conduct, which is called "Eve teasing" in India. 58

Within American cities, harassment is more common in certain places than others. Construction sites are perennial problems, and

${ }^{54}$ See Del Sesto, supra note 53, at $\mathrm{B}_{4}$ (suggesting that the high rate of unemployment, and thus of men congregated on street corners, may be one cause); see also Courtland Milloy, The Ugly Sounds of Summer, WASH. PoST, May 3I, I990, at JI (recounting one commentator's perception that street harassment in Washington, D.C., is worse than in other major cities in which she has lived).

55 Florence King, The Good Ole Boy: A Southern Belle's Lament, HARPER's, Apr. 1974, at $78,79$.

56 See, e.g., WiSE \& STANLEY, supra note 35, at I72; Kissling, supra note 7, at 45I-52; Lindsy Van Gelder, The International Language of Street Hassling, Ms., May I981, at 15, 15r8. Kissling notes that one of the most valuable features of the 1986 women's travel guide Half the Earth is its detailed, country-by-country descriptions of harassment and how the tourist should cope with it. See HALF THE EARTH passim (Miranda Davies, Laura Longrigg, Lucinda Montefiore \& Natania Jansz eds., I986); Kissling, supra note 7, at 452.

57 See, e.g., Kathy Evans, Dress Code Enforces Secondary Role, Fin. TimEs, Apr. I, I985, $\S \mathrm{III}$, at xvi (comparing treatment of women on streets in Iran under the regimes of the Shah and of his fundamentalist successors).

58 See India to Set Up Women-Only Police Squad, REUTERS, Jan. 3, I986, available in LEXIS, Nexis Library, Omni File. 
the presence of street pornography in an area seems to increase the likelihood of hassling, perhaps by symbolically condoning sexist attitudes and behavior. ${ }^{59}$ Some women report that they are spared stares and comments when they are in public places traditionally associated with the home, such as department stores, grocery stores, and churches; ${ }^{60}$ but others write of unpleasant encounters in these places as well. ${ }^{61}$ In addition, both personal and shared experiences reveal that men in trucks often harass women in cars. The r991 movie Thelma and Louise graphically depicted this particular form of harassment. (The movie's two female protagonists ultimately confront their harasser and blow up his truck, usually to the cheers of the audience.) ${ }^{62}$ Case law and recent news articles show that taxicabs are also a common venue for harassment. ${ }^{63}$

Benard and Schlaffer's empirical study indicates that there are some places, such as small villages, in which street harassment does not occur. This discovery led the authors to conclude that harassment is confined to the "genuinely public world," where people are strangers to one another. ${ }^{64}$ Apparently if someone exists for you as an indivi-

${ }^{59}$ See di Leonardo, supra note 35 , at 55.

60 See KRAMARAE, supra note 22, at I42:

61 See Marie Shear, Free Meat Talks Back, J. Comm., Winter 1976, at 38, 38-39 (describing an interchange in a candy store).

62 Some reviewers said that the audience as a whole cheered at the violence in Thelma and Louise; others either said or implied that the cheers came primarily from the women in the audience. Compare Ruth Walker, Why We Cheered 'Thelma \& Louise', Christian Scr. MoNITOR, July I7, I99I, at 58 ("The crowd in our little cinema off Harvard Square burst into whoops and cheers . ...") with Charles Bremner, Giving as Bad as They Get, The Times SATURDAY REVIEW, June 29, I991, at 6 ("Women in the big cities are cheering it in the cinema, while men laugh nervously.") and Diane White, The Great Debate over Thelma and Louise, Boston Globe, June 14, I991, at 29 ("There were about three times as many women as men in the audience when I saw 'Thelma and Louise.' They cheered when Louise plugged the roadhouse cowboy who was trying to rape Thelma. And when the two characters blew up the rig of a leering, tongue-waggling trucker, they cheered even louder."). One reviewer explained why women might react with such exuberance, despite the violence, making explicit the connection of this response to women's experience of street harassment: "At this point, another wave of cheers swept the audience. Here was a symbolic destruction of not only every lewd truck driver but every construction worker whistling unwanted whistles, every all-purpose masher preventing a woman from enjoying a public place, every dirty-minded boy we had to endure in school." Walker, supra, at r8. I share this understanding, for seeing the movie was one of the events that inspired me to write this Article.

${ }^{63}$ See Plummer v. City of Columbus, 414 U.S. 2, 3-4 (1973) (recounting how a taxi driver addressed a female fare with vulgar, suggestive, and sexually-oriented statements); Lamar v. Banks, 684 F.2d 714, 715 (1rth Cir. 1982) (describing an event in which a taxi driver drove a college student to an unfamiliar area, where he told her, "I bet your honey doesn't have the nine and one-half inch penis I have."); Robert Davis, Rude Taxi Drivers Find City Is Indeed Talking to Them, CHI. TRIB., Sept. I8, I99I, § 2, at $\mathrm{r}$ (reporting that a taxi driver dropped his pants during a dispute with a female passenger); see also People v. Dick, 505 N.E.2d I157, II59 (Ill. App. Ct. 1987) (reporting that a passenger was raped by a taxi driver).

64 Benard \& Schlaffer, supra note $\mathrm{I}_{3}$, at 72. 
dual, you are less likely to harass her - a fact reflected in the prototypical question used to confront harassers: "Would you want someone to treat your sister (or wife, or mother) this way?"65

\section{Harassers and Their Targets: Who Are They?}

As should be clear from these accounts, the men who harass women in the street are not just construction workers; they include bus and taxi drivers, train conductors, males congregated on the streets, "Good Ole Boys," and passers-by. The activity crosses lines of geography, religion, race, age, and class. As one observer has suggested, the only reason street harassment superficially appears to be an institution of working-class men is that their place of business is more often the street. ${ }^{66}$ Benard and Schlaffer, who personally tested their hypotheses by acting as "testers" on the streets, reported that age, education, and income bore little relation to harassing behavior (although younger men tended to be more aggressive, and older men tended to lower their voices). ${ }^{67}$

The target of street harassment is literally every woman between the age when her body begins to develop sexually and that undefined point when she is no longer assumed to be a sexual being because she is "too old." Different women may experience street harassment in different ways, though. For a very young girl, it is one of her first lessons in what it means to be a sexual being - a confusing and shame-producing experience. According to Robin West:

Street hassling is also the earliest - and therefore the defining lesson in the source of a girl's disempowerment. If they haven't learned it anywhere else, street hassling teaches girls that their sexuality implies their vulnerability. It is damaging to be pointed at, jeered at, and laughed at for one's sexuality, and it is infantilizing to know you have to take it. 68

Lesbians are subjected to a uniquely offensive experience, as they are both "punished" for being women and assumed to be what they are

\footnotetext{
65 For example, the women in the movie Thelma and Louise, attempting to obtain an apology from their harasser before blowing up his truck, asked him whether he would want someone to talk like that to his sister. This was also the touchstone upon which the judge in the 1875 case against the Chicago and Northwestern Railway measured the appropriate damages for the schoolteacher assaulted by the Railway's conductor. The judge asked rhetorically, "Who can be found to say that such an amount would be in excess of compensation to his own or his neighbor's wife or sister or daughter?" Craker v. Chicago \& N.W. Ry., 36 Wis. 657, 679 (I875).

${ }^{66} \mathrm{See}$ Kissling, supra note 22, at 5. Studies of workplace harassment now suggest that men who work in offices get - and take advantage of - many other chances to sexually harass women. See, e.g., GuTEK, supra note 2, at 42-60; MAcKINNoN, supra note 2, at 25-47.

${ }^{67}$ See Benard \& Schlaffer, supra note 13 , at 72; see also Gardner, supra note 20 , at 333 ("Street] remarks are delivered by all classes and races of men, singly and in groups.").

68 West, supra note 9, at Io6.
} 
not - heterosexual. On the other hand, if it is obvious that they are lesbian, men harass them for that status as well. ${ }^{69}$

The experience of street harassment may also differ with the race, class, or ethnicity of the targeted woman and the history of gender interactions to which she has become accustomed. Although it would be impossible adequately to describe all of these disparate reactions, it is useful to note some differences between the harassment experience of African-American women and of European-American women. In many African-American communities, men and women engage in sexually oriented banter in public; several writers have pointed to similarities between street harassment and these forms of repartee. ${ }^{70}$ Others conclude that African-American women are therefore not harmed by street remarks. ${ }^{71}$ Yet, although "rapping" may resemble some forms of street harassment in some respects, this custom is also distinguishable from street harassment, because women are not ratified speakers in the typical harassment context, but are merely intended overhearers. ${ }^{72}$ Furthermore, badinage, or humorous banter, is a mutually agreed-upon interaction, whereas street harassment takes place and persists even when the woman actively avoids interaction. ${ }^{73} \mathrm{Fi}$ nally, it should be noted that, although many African-American women respond assertively to rapping, they typically do not initiate it. Thus, even in this context, speech rights are asymmetrical. ${ }^{74}$

Although African-American women may be familiar with forms of interaction similar to street harassment and thus may experience harassment as something akin to a familiar gender interaction, it does not necessarily follow that they like it. I have not located any accounts in which Black women stated that they enjoyed street harassment. Rather, it is clear from newspaper stories that African-American women suffer great pain from street harassment and that in many large cities such harassment can be both more frequent and more intense for them than for other women. ${ }^{75}$ One African-American

69 See Gary D. Comstock, Violence Against Lesbians and Gay Men I41-44 (I991) (summarizing the author's survey of reported experiences of anti-gay and anti-lesbian verbal harassment); RUTHANN ROBSON, LESBIAN (OUT)LAW: SURVIVAL. UNDER THE RULE OF LAW I45-56 (1992) (discussing violence against lesbians).

${ }^{70}$ See Gardner, supra note 20, at 339-40; Kissling, supra note 22, at II; Kramarae, supra note 8 , at $9 \mathrm{I}-92$.

${ }^{71}$ Cf. Orlando Patterson, Race, Gender and Liberal Fallacies, N.Y. Times, Oct. 20, 1991, $\S 4$, at I5 (suggesting that Supreme Court nominee Clarence Thomas had merely engaged Anita Hill in a verbal style with which both were familiar as African-Americans of similar background, but that the congressional hearings thrust his remarks into a context in which they were evaluated, inappropriately, according to white, middle-class, neo-Puritan (feminist) values).

72 See Gardner, supra note 20, at 338-40.

${ }^{73}$ See di Leonardo, supra note 35 , at 52.

74 See Kissling, supra note 22, at 12.

75 See Milloy, supra note 54 , at Jr. 
woman described the difference between the interactions to which she was accustomed and those that she encountered upon moving to Washington from the South:

I come from . . . the South. Where I'm from, black men and women address each other on the street. Those who don't are considered rude, ill-bred and hateful of black tradition. So I once had no qualms about speaking to men on the street.

But in the past few months of living in Washington, I have lost the ability to discriminate between men who are being friendly and those who wish to do me harm. Now I view all gestures from men on the street as potential threats. All the car honks and "hey-baby" comments that I once considered just annoying are now ominous and alarming. ${ }^{76}$

In short, despite familiarity with forms of interaction superficially similar to street harassment, African-American women are also offended by it.

Moreover, Black women are harassed by both white and Black men - experiences that evoke different historical associations. Historically, African-American women have been subjected to particularly virulent and degrading forms of harassment by white men. They were treated as the sexual property of their masters during slavery, and this attitude survived emancipation. ${ }^{77}$ A typical modern interchange is described in a scene in Lorraine Hansberry's To Be Young, Gifted and Black:

In these streets out there, any little white boy from Long Island or Westchester sees me and leans out of his car and yells - "Hey there, hot chocolate! Say there, Jezebel! Hey you - 'Hundred Dollar Misunderstanding' YOU! Bet you know where there's a good time tonight . . . ."78

bell hooks has accurately explained this exchange as premised upon the assumption that all Black women, regardless of their class, are prostitutes and are available as sex objects. ${ }^{79}$ Thus, when African-

\footnotetext{
76 Emily Bernard, Black Women and the Backwash of Harassment, WASH. Post, Aug. I2, 1990, at C8. A 29-year-old Mexican-American woman living in Washington also described the situation as a "nightmare" and reported that "I'm afraid everyday that a verbal assault is going to turn into a physical one." Del Sesto, supra note 53 , at $\mathrm{B}_{4}$.

77 See, e.g., Angela Y. Davis, Women, Race \& Class 23-25 (I98I); Paula Giddings, When AND Where I ENTER: THe IMPACT OF BlaCK WOMEN ON RACE AND SEX IN AMERICA 43-46 (1984). For a description of the differences in the way Black women and white women may experience rape as well, see Angela P. Harris, Race and Essentialism in Feminist Legal Theory, 42 STAN. L. REv. 58I, 598-60I (I990); and Kimberle Crenshaw, Demarginalizing the Intersection of Race and Sex: A Black Feminist Critique of Antidiscrimination Doctrine, Feminist Theory and Antiracist Politics, I989 U. CHI. LEGAL F. 139, 157-60.

78 LORRAINe HaNSBERRy, To BE Young, GIFTEd AND BLACK 77 ( 1969 ).

79 See Bell hooks, Ain't I A WoMAN: BlaCK WoMEN AND FeMinism 58-59 (198I).
} 
American women are harassed on the street, the experience evokes a long history of disrespect, degradation, and inhumane sexual mistreatment to which Black women have been subjected over the years. One woman has tried to convey this message to African-American men who engage in street harassment:

I would like to address a special concern to those black men who are making the District a living hell for their sisters.

... Your lewd invitations and crude commands may seem funny to you, but the truth is that nothing comes closer to the slave-era mentality of white men toward black women.

Young black men yell at women who are mothers, "Come here, girl!" They whistle at women as if calling dogs. Even black children are not immune. I heard a grown man tell a I2-year-old, "I'll be back when you get a little older, baby."

Hence, despite familiarity with sexual repartee on the streets, Black women may in fact suffer more intensely from street harassment than other women, because it resonates with remnants of a slave-era mentality.

In sum, although women from different backgrounds may experience street harassment through the lens of different historical and personal experiences, at base it remains an unwelcome and painful event for us all. ${ }^{81}$ In this sense, it is also a universalizing experience - one that virtually all women share. Indeed, its near-universality denotes the extent to which such harassment is simply accepted as normal and thus becomes invisible as a social problem. This invisibility may in turn account for the relative silence about street harassment in any form of legal literature.

\section{What Are the Legally Cognizable HARMS OF STREET HARASSMENT?}

Although street harassment affects women's psychological wellbeing and conduct, in the cold light of the law the question is whether this impact rises above the ordinary annoyances that citizens must

80 Milloy, supra note 54 , at Jr.

81 One must note that there are women who report that they like being the object of sexual attention from strangers on the street. See, e.g., Letters from Readers, Glamour, Nov. 1992, at 44 ("Being whistled at, called "baby' and generally admired is fun and harmless."). Their accounts, however, do not describe interactions of the brutal and openly degrading types discussed above, but rather the experience of being the target of wolf-whistles, evaluative commentary of a positive sort, and remarks of the "Hi, baby!" variety. Although most women find this attention burdensome, some profess to find it complimentary. Some authors suggest that this flattered reaction is a form of false consciousness created by the repeatedly disempowering experience of street harassment. See, e.g., West, supra note 9, at 85. At any rate, the fact that some women are greatly harmed by harassment on the street, see infra pp. 535-40, surely outweighs the pleasure others may profess to feel from this attention. 
endure as the price of living in society. ${ }^{82}$ To answer this question, one must return to the accounts that women have given of their individual and collective experiences as targets on the street. These accounts demonstrate that street harassment not only has a significant impact upon the lives of women as individuals, but also has significant consequences for society as a whole.

\section{A. The Impact of Street Harassment upon Women}

Street harassment evokes from its targets emotional responses that range from moderate annoyance to intense fear. Two themes repeatedly appear in women's responses to inquiries about the experience of harassment: the intrusion upon privacy and the fear of rape. For example, eight of the ten women interviewed by Carol Brooks Gardner referred to street harassment as an invasion of privacy, and an equal number mentioned similarities to rape. ${ }^{83}$ Many women apparently view the issue as one of privacy and offer remarks such as: "Women have traditionally been considered weak and vulnerable, thus it is safe to intrude on their privacy. The reason I hate to be whistled at is I feel like that person is forcing his way into my space, whether I like it or not." 84 Other women point to women's constant fear of rape and remark that there is no way of knowing which stranger will in fact turn out to be a rapist. ${ }^{85}$ Thus, each time a strange man addresses a woman on the street, she must entertain the possibility that he might rape her.

Women have good reason to believe that street harassment can serve as a precursor to rape. Although most encounters may turn out

82 See, e.g., William L. Prosser, Intentional Infiction of Mental Suffering: A New Tort, 37 Mich. L. REv. 874, 887 (1939) ("The rough edges of our society still are in need of a great deal of filing down, and the plaintiff in the meantime must necessarily be expected and required to be hardened to a certain amount of rough language, and to occasional acts that are definitely inconsiderate and unkind."). Prosser's comments were incorporated into the Restatement (Second) of Torts. See Restatement (SECOND) OF Torts $\$ 46 \mathrm{cmt}$. d (1965). As Charles Lawrence points out, however, subordinated groups are frequently called upon to pay this price on behalf of the society as a whole. See Charles R. Lawrence III, If He Hollers Let Him Go: Regulating Racist Speech on Campus, Iggo DuKE L.J. 43I, 456, 472-73.

${ }^{83}$ See Gardner, supra note 20 , at $352 \mathrm{nn} .8$ \& ro.

84 Kissling \& Kramarae, supra note 22, at 83 (quoting a participant in a discussion of street remarks that was conducted on a computer system). Similarly, a woman jogger reported:

For more than two years, I have run six miles every afternoon on the riverside paths of Minneapolis-St. Paul. There has rarely been a time, even in these well-behaved cities, when men have not shouted obscenities at me. I have been honked at, whistled at and had beer cans thrown at me. ...

On one recent run I was accosted by an exhibitionist. My reaction wasn't shock, but rage that once again someone was shattering my peaceful hour alone outdoors . . . .

Karin Winegar, What I Want Is an Hour on the Jogging Path Without Men's Catcalls. Is that Too Much to Ask?, GlamoUr, June I980, at I86, 186.

${ }^{85}$ See Kissling \& Kramarae, supra note 22, at 84-85. 
to be innocuous, this fear is not unrealistic, given that as many as one in three women in our society have been victims of rape or attempted rape at some time in their lives. ${ }^{86}$ Furthermore, rapists often harass women on the street and violate their personal space in order to determine which women are likely to be easy targets - a practice called "rape-testing." 87 Because potential rapists frequently select their victims by looking for women who appear vulnerable to assault, they may approach a potential victim and "test" her by a variety of means, including making lewd or insinuating remarks, to see if she can be intimidated. ${ }^{88}$ If the target reacts in a passive fashion to the harassment, the rapist may assume that she will probably not fight back, and he is more likely to rape her. ${ }^{89}$ Thus, the connection between rape and harassment is not just in the mind of the woman.

Women who have been victims of rape are especially vulnerable to the harms that street harassment inflicts. If as many as one out of three American women has been subjected to rape or an attempted sexual assault, the target of street harassment may well be a woman who carries this traumatic history within her. Thus she may be both especially fearful and especially traumatized by an encounter on the streets. ${ }^{90}$ Although a harasser generally cannot ascertain whether a particular target has been raped, the statistics on rape make this possibility of heightened injury foreseeable. Even if a target who has previously been raped reacts with fear or panic out of proportion to the nature of the remark addressed to her, hers is an "eggshell" shared

\footnotetext{
${ }^{86}$ Recent statistics from a government-funded study indicate that one of every eight adult women in America has been raped at least once. See Study: Rapes Far Underestimated, CHr. TrIB., Apr. 24, I992, § I, at 3. Earlier Department of Justice statistics indicated that at least II\% of women interviewed reported that they had been raped or sexually assaulted at some time during their lives. Women who live in large cities, however, have a one-in-five to one-ineight chance of being raped during their lifetimes, and perhaps even a one-in-three chance in certain areas. See Margaret $T$. Gordon \& Stephanie Riger, The Female Fear 36 (1989). Other studies show that as many as $44 \%$ of women were victims of rape or attempted rape at some time in their lives. See Diana E.H. Russell \& Nancy Howell, The Prevalence of Rape in the United States Revisited, 8 Signs 688, 690 (1983).

${ }^{87}$ See, e.g., Dana, supra note 27 , at $\mathrm{C}_{5}$; Del Sesto, supra note 53 , at $\mathrm{B}_{4}$.

88 See Dana, supra note 27 , at $\mathrm{C}_{5}$; see also Judith Fein, ARE You a TARget?: A Guide to Self-Protection, Personal Safety, aNd Rape Prevention 27 (1981) (noting that a rapist, when approaching to test his victim, "may very well threaten to kill her" and "may be hostile, abusive, hateful and threatening").

${ }^{89}$ See FEIN, supra note 88 , at 27-28.

90 A former rape victim interviewed by Diana Russell stated, for example:

"When I first started to live in the city, I would walk by the construction workers having lunch and hear all these horrible comments. I didn't quite know how to deal with it. . . .

"Encounters on the street are annoying but not, of course, as serious as actual rape. When I feel strong, when I feel together, I am able to handle them. But when I feel a little bit under, and not quite coping with things, these experiences leave me with a very bad feeling."

Diana E.H. Russell, The Politics of Rape 168 (r975).
} 
by millions of women. ${ }^{91}$ However, even if the injury were not so foreseeable, the harasser would still be liable. ${ }^{92}$

Although women are deeply harmed by the fear street harassment arouses, their immediate reactions to it are often counterproductive. Women who are harassed on the street typically do not respond to the harasser but instead try to ignore him, or, more accurately, pretend to ignore him. Women may react this way because they are unwilling to admit their powerlessness in the situation, ${ }^{93}$ are afraid of physical attack, ${ }^{94}$ or are reluctant to draw attention to themselves or to be displeasing. ${ }^{95}$ In other circumstances, they are simply annoyed and do not want to reward the harasser with a response, or they are embarrassed to have been treated in such a degrading manner. They freeze; they put on a blank face; they try to pretend that nothing is happening. ${ }^{96}$ When women take these evasive actions in an effort to mask feelings of invasion, anger, humiliation, and fear, they suffer a psychological beating in the form of emotional distress and feelings of disempowerment. ${ }^{97}$ By contrast, one study of rape victims revealed that women who resisted rape, even when they failed to prevent it, were less likely to feel depressed after the assault than those who did not resist; the women who resisted even experienced a degree of psychic liberation. ${ }^{98}$ Thus, nonresponse to street harassment may impose its own costs.

Harassment also takes a toll on women's self-esteem. Street harassment reduces women to sexual objects. The comments and conduct of a harasser then force this perception upon his target. One woman explained:

91 The allusion, of course, is to the concept of an "eggshell plaintiff" in tort law - one who is injured far more easily than the tortfeasor might realistically imagine - and to the proposition that the tortfeasor must take his victims as he finds them. See Restatement (SECOND) of TORTS $\$ 46 \mathrm{I}$ (rg65).

92 See, e.g., Vosburg v. Putney, 50 N.W. 403, 403-04 (Wis. I89I) (holding the tortfeasor, a I2-year-old schoolboy, liable for all of the injuries he caused, whether or not foreseeable, resulting from his wrongful act (kicking a classmate in the shin)).

${ }_{93}$ See di Leonardo, supra note 35 , at $5 \mathrm{r}$.

94 See, e.g., Kristin Anderson, Letter to the Editor, USA ToDAy, July I9, I99I, at IIA ("I was walking down the street the other day, wearing nothing revealing. This man was flicking his tongue at me and asked me if I tasted as good as I looked. There is nothing you can do about it. What if you get someone mad? You don't know who they are, and you might end up raped or killed.").

${ }_{95}$ Medea and Thompson believe that women do not respond when harassed because they are "conditioned to be afraid of men under any circumstances and to be afraid of offending them even when there is no possible basis for their fear." ANDRA MEDEA \& KathleEN ThOMPSON, AGAINST RAPE 52 (1974).

96 See Gardner, supra note 20, at 345 . Some add sunglasses and a Walkman to become even more inscrutable. See Blair, supra note 24 , at 184 .

97 See MEdEA \& Thompson, supra note 95 , at 49-55.

98 See Pauline B. Bart \& Patricia H. O'Brien, Stopping Rape: Successful Survival STRATEGIES $42-43$ (Ig85). 
While it is true that for these men I am nothing but, let us say, "a nice piece of ass," there is more involved in this encounter than their mere fragmented perception of me. They could, after all, have enjoyed me in silence. . . . But I must be made to know that I am "a nice piece of ass"; I must be made to see myself as they see me. ${ }^{99}$

One author describes the reaction of women to being forced to perceive themselves as objects as a form of "madness":

Being the Subject-as-Object is maddening. It is to be both Self and Other, and to be torn between them. In such a divided state of mind, one's perceptions of others, of one's relations to them, and of oneself become untrustworthy. This chaotic moment can seem like madness, to which one responds with a desperate struggle to understand and explain. When, then, a woman turns into the Subject-as-Object, as in street hassling, she can feel as though she were losing her mind. 100

Although "madness" might seem an extreme description, studies of sexual harassment in the workplace show that its victims suffer severe emotional distress, often accompanied by depression, anxiety, stress, loss of motivation, and guilt, as well as disgust, hurt, and anger. ${ }^{101}$ Likewise, according to psychologists, women subjected to public insults on the street suffer a psychological toll from "ffeel[ing] degraded, embarrassed, angry and helpless."'102 Harassment may also teach women to be ashamed of their bodies and to associate their bodies with fear and humiliation. Not only does this result harm a woman's self-esteem, but it may also interfere with her ability to be comfortable with her sexuality. ${ }^{103}$

99 Sandra L. Bartky, On Psychological Oppression, in PHiLosophy AND WoMen 33, 37 (Sharon Bishop \& Marjorie Weinzweig eds., 1979).

100 Dimen, supra note I, at ro; see also Meredith Tax, Woman and Her Mind: The Story of Everyday Life, in RADICAL FEMINISM 23, 28-3I (Anne Koedt, Ellen Levine \& Anita Rapone eds., 1973) (describing this psychological distress as a form of schizophrenia). Tax describes a woman walking past a construction site attempting to shut out the pain of verbal assaults by splitting her mind from her body so that they can't "get her." See id. at 28; see also Blair, supra note 24 , at 184 ("Because he objectified me, I was forced to objectify myself, and it made me feel divided in two.").

101 See, e.g., GuTEK, supra note 2, at 70-71; James E. Gruber \& Lars Bjorn, Women's Responses to Sexual Harassment: An Analysis of Sociocultural, Organizational, and Personal Resource Models, 67 Soc. ScI. Q. 814, 817 (1986); David E. Terpstra \& Douglas D. Baker, $A$ Hierarchy of Sexual Harassment, 12 I J. PsYchol. 599, 599 (1987).

102 Dana, supra note 27, at $C_{5}$ (quoting Dr. Catherine Bernard).

103 Jennifer Nedelsky points to the connection between the shame women are taught to feel about their bodies and a more general sense of inadequacy. See Jennifer Nedelsky, Inadequacy and Disentitlement: Internal Barriers to Women's Equality 20 (Aug. I99I) (unpublished manuscript, on file at the Harvard Law School Library). Iris Young also speculates that the general lack of confidence that women frequently have about their cognitive and leadership abilities is traceable in part to doubt about their bodies, which is exacerbated by repeated invasions of their personal space. See IRIS M. Young, Throwing Like a Girl: A Phenomenology of Feminine Body Comportment, Motility, and Spatiality, in Throwing LIKe A GIRL ANd OTHER Essays in Feminist Philosophy and SOCIAL Theory I4I, I55-56 (1990). 
Finally, street harassment severely restricts the physical and geographical mobility of women. It not only diminishes a woman's feelings of safety and comfort in public places, but also restricts her freedom of movement, depriving her of liberty and security in the public sphere. ${ }^{104}$ Women avoid certain places, sites, or activities (biking and jogging are common examples) for years in order to escape harassment. ${ }^{105}$ Students in Washington, D.C., take detours or beg rides in order to avoid being hassled. ${ }^{106}$ Thus, harassment makes the urban environment uncomfortable, hostile, and frightening for women. ${ }^{107}$ In this way, street harassment restricts women's mobility in a way that substantially offsets the gains women have made in other spheres:

In an era when women are indeed exercising hard-won options in areas such as employment, childbearing, and politics, they often seem to be limited in simpler choices - whether to go to the movies alone, where to walk or jog, whether to answer the door or telephone. Can we measure the success of a social movement for equality if we do not include an assessment of the quality of life of the affected groups? ... Without such freedom it is impossible to implement other choices. ${ }^{108}$

Fears of rape as well as of harassment itself underlie these restrictions upon women's mobility. It is usually difficult, however, to disentangle the effects of street harassment from the effects of fear of sexual assault. Harassment in dangerous areas, such as "dark alleys,"

104 See, e.g., di Leonardo, supra note 35 , at $5 \mathrm{I}$. Restricted movement because of safety concerns is a problem shared by other groups within our society, such as residents of public housing. See, e.g., AleX Kotlowitz, There ARE No ChILdRen HERE 26, 252-53 (I99I) (describing how violence in the neighborhood restricts mobility of children and adults even in their own apartments in Chicago public housing).

105 See Gardner, supra note 20, at 345 .

106 See Dana, supra note 27 , at $\mathrm{C}_{5}$.

107 Mazey and Lee conclude that the result of harassment is "that streets, sidewalks, and other spaces, where men roam freely, become zones of hostile space for women." MARY E. Mazey \& David R. Lee, Her Space, Her Place (1983), quoted in Belinda Leach, Ellen Lesiuk \& Penny E. Morton, Perceptions of Fear in the Urban Environment, 8 WoMEN \& ENv'TS 10, Io (1986).

108 Carole Sheffield, Sexual Terrorism: The Social Control of Women, in ANalyzing GenDER: A HANDBOOK OF SOCIAL SCIENCE RESEARCH I7I, I7I (Beth B. Hess \& Myra Marx Ferree eds., I987). Adrienne Rich makes a similar point in relation to women's access to education:

The undermining of self, of a woman's sense of her right to occupy space and walk freely in the world, is deeply relevant to education. The capacity to think independently, to take intellectual risks, to assert ourselves mentally, is inseparable from our physical way of being in the world, our feelings of personal integrity.

Adrienne Rich, Taking Women Students Seriously, in On Lies, SeCrets, ANd Silence 237, 242 (1979). Rich makes this comment in the context of the fear of rape, but the fear of violent assault is part of the fabric that underlies the anxieties aroused in women by harassment. In the individual case, they are thus hard to separate. 
in fact arouses realistic fears of rape. Furthermore, all harassment takes place in a social context in which women are always conscious of the threat of rape. Consequently, any incident of harassment, no matter how "harmless," both evokes and reinforces women's legitimate fear of rape. ${ }^{109}$ It does so by reminding women that they are vulnerable to attack and by demonstrating that any man may choose to invade a woman's personal space, physically or psychologically, if he feels like it. ${ }^{110}$ Thus, street harassment forms part of a whole spectrum of means by which men objectify women and assert coercive power over them, one which is even more invidious because it is so pervasive and appears, deceptively, to be trivial.

\section{B. The Consequences of Street Harassment for Women, Gender, and Society}

The fear, psychological trauma, and restrictions on personal liberty described above have obvious consequences for women as individuals. Not so obvious, perhaps, are the consequences suffered by society as a whole. In fact, the harms of street harassment extend to its impact upon the relationship between the sexes, upon the construction of gender in our society, and upon social and political relationships in general.

First, street harassment both increases women's dependence on men and contributes to distrust and hostility between the sexes. For example, street harassment, and the related danger of sexual assault, encourage women to seek male escorts in public - men to protect them from harassment by other men - what Susan Griffin has referred to as the male "protection racket."111 Moreover, it is difficult for a man, however well-intentioned, to address an unfamiliar woman on the street without evoking some suspicion or fear in her, unless he goes to some lengths to assure her that he - unlike other unfamiliar males - is indeed trustworthy. ${ }^{112}$ Thus, the possibility of harassment

${ }^{109}$ See Barbara Houston, What's Wrong with Sexual Harassment, ATLANTIS, Spring 1988, at 44,46 .

110 See Dimen, supra note $\mathrm{I}$, at 4. Muriel Dimen views street hassling as a characteristic example of this coercive lesson, showing that men have the power to say anything to women, who lack reciprocal power. See id.

111 See Susan Griffin, Rape: The All-American Crime, in Women: A Feminist Perspective 24, 30 (Jo Freeman ed., I975); see also NaNCy Henley, Body Politics: Power, SEx, AND NoNVERBal Communication 63 (1977) (analogizing the arrangement by which women need male escorts to protect them against attack by men to a criminal "protection racket").

112 See Brent Staples, Just Walk on By: A Black Man Ponders His Power to Alter Public Space, Ms., Sept. 1986, at 88 (describing incidents in which the author unintentionally frightened people). 
complicates casual communication and impedes solidarity among unacquainted men and women. 113

Second, contrary to the folk wisdom that "sticks and stones may break my bones but words will never hurt me," language is instrumental in the construction of reality; language locates individuals within that reality and thus constructs their gender identities. ${ }^{114}$ Women learn to associate their bodies with shame, fear, and humiliation. ${ }^{115}$ Women also learn their place in society from language, and they learn that this place is not a public one. The remarks women hear from harassers on the street carry the implicit (and sometimes explicit) message that women do not belong in public, where they draw attention by their mere appearance, but rather in the private sphere, at home. As one woman who experienced street harassment explained:

Home was still the only place women didn't need an excuse to be. . . . It [the street] was their [men's] turf, the place where they belonged. Perhaps they hadn't actually pissed at all the crosswalks like territorial tomcats, but then they didn't have to. After all, who was going to challenge their domain? ${ }^{116}$

Indeed, many analysts conclude that the intent of street harassers is, in fact, to remind women of their gender identity and their place in society. ${ }^{117}$ Although it is dangerous to reason from effects to intentions, this hypothesis has explanatory power. In primitive societies, for example, women who obey the accepted rules of behavior are not sexually molested, while those who break the taboos are seen as asking for trouble. ${ }^{118}$ Similarly, street harassment in modern cities keeps women in their place, reinforces the private-public split, and maintains a hierarchy of gender in everyday life. One writer describes this function as follows:

The first function of public harassment is to reinforce spatial boundaries that drastically limit women's "sphere." It clearly stakes out public space as male space. Women who want to be outside their

113 See Goffman, supra note 32, at 142. Ironically, Goffman makes this point as a throwaway to his consideration of the problem of "pickups" by homosexual males on the streets. The problem created by this, he says, is that it makes other males unsure of themselves and threatens casual solidarity among unacquainted males, thus doing "to the all-male (and to a degree to the all-female) world what has already been done to communication contacts between the sexes." Id.

114 For a good short description of this analysis, based on the work of Jacques Lacan, see KRAMARAE, cited above in note 22 , at $64-72$.

115 See Nedelsky, supra note I03, at 20; West, supra note 9, at ro6-08.

116 Blair, supra note 24 , at II 8 , I84

117 See, e.g., Kissling \& Kramarae, supra note 22, at 76; Kramarae, supra note 4, at rog.

118 See Margaret Mead, A Proposal: We Need Taboos on Sex at Work, REDbook, Apr. 1978, at $3 \mathrm{r}, 3 \mathrm{r}$. 
homes must do so at their own risk and with the full knowledge that at any time they can be publicly humiliated or "complimented." Women are at all times subject to public scrutiny. ${ }^{119}$

The woman who is its target, of course, cannot know what psychological role harassment is fulfilling for the individual who accosts her; she is left simply with the message it conveys. For this reason, it seems safe to leap, if not from effect to intention, then from effect to social function and to conclude that "[h]arassment is a way of ensuring that women will not feel at ease, that they will remember their role as sexual beings available to men and not consider themselves equal citizens participating in public life."120 For those of us who believe in the ideal of equality, such a result is damaging not only to half of the human population, but to society as a whole.

In sum, the continuation and near-general tolerance of street harassment has serious consequences both for women and for society at large. It inflicts the most direct costs upon women, in the form of fear, emotional distress, feelings of disempowerment, and significant limitations upon their liberty, mobility, and hopes for equality. It also increases distrust between men and women and reinforces rigid gender roles, hierarchy, and the confinement of women to the private sphere. Street harassment thus performs a function as a social institution that is antithetical to the acceptance of women into American public life on terms equal to men.

\section{Freedom of Speech and the Balance of Harms}

Given the very real harms I have described, are there countervailing considerations that outweigh the detriment to women and society and militate in favor of protecting the forms of speech represented by street harassment? To answer this question, one must first assess the value of harassment to the men who engage in it.

There is some empirical evidence about why men harass women on the street. Benard and Schlaffer interviewed sixty men who harassed them on the street, choosing their subjects from a variety of age groups. ${ }^{121}$ When asked why they hassled women, most of the men responded that harassment alleviated boredom, was "fun," and gave them a feeling of camaraderie with other men; many added,

119 Pam McAllister, Wolf Whistles and Warnings, 6 Heresies 37, 37 (1978).

120 Benard \& Schlaffer, supra note 13 , at 72.

121 See id. at 7I. Benard and Schlaffer report that a sure-fire way to stop a harasser is to whip out a questionnaire and inform him that he is part of a research project, but also note that this approach is more than a little time-consuming. See id. 
defensively, that it didn't hurt anybody. ${ }^{122}$ Some said it was intended as a compliment. ${ }^{123}$ Twenty percent said that they would not engage in the behavior alone but only did so when they were in groups of men - a finding that supports a "male-bonding" explanation of harassment as a form of demonstrating solidarity and mutual power. ${ }^{124}$ A minority, approximately fifteen percent, who were also the group that employed the most graphic commentary and threats, said explicitly that they intended to anger or humiliate their victims. ${ }^{125}$ To all of these explanations one must add, as noted above, that harassment can also serve as a method to select rape victims. ${ }^{126}$

In short, the most lofty motivations described by those surveyed amounted either to misguided attempts to render a compliment or simply to enjoyment of a sport that contributes to male-bonding but is carried out at the expense of women's liberty, security, and equality. Under a utilitarian calculus, the value of harassment to men who enjoy it simply does not outweigh its detrimental impact on women and society.

The constitutional question, then, is whether the First Amendment reverses the outcome of this utilitarian analysis. I believe that most, if not all, measures to regulate street harassment and to give redress to its targets can withstand scrutiny under the First Amendment.127 First, many of the speech acts that constitute street harassment simply do not fall within the commonly accepted boundaries of the First Amendment. Whether verbal or not, behavior that constitutes an

122 See id. Descriptions in literature by men tend to support the sportive or recreational explanation. See Gardner, supra note 20, at 354 n.I8 (citing JAMES T. FARrell, STUDS Lonigan i22-23 (I935); Thomas Pynchon, V. 32-34 (I96I); and Alan Sillitoe, The LoneLINESS OF THE LONG-DISTANCE RUNNER I48-49 (I959)).

123 See Benard \& Schlaffer, supra note I3, at 7I. As several authors point out, street remarks, even if positive in tenor, violate important norms of compliment behavior, because they occur in a public place between unacquainted persons and frequently refer to parts of the body that are private. See Gardner, supra note 20, at 340-4I, 344; Kissling, supra note 22, at 13. Gardner also points out that the parody of a compliment is not a compliment at all. Gardner, supra note 20 , at 344 .

124 See Benard \& Schlaffer, supra note 13 , at $7 \mathrm{I}-72$.

$125 \mathrm{See}$ id. at $7 \mathrm{I}$. Gardner posits that harassment allows men to displace anger or hostility toward women onto women whom they do not know and to do so in a low risk situation, because the target is a moving one. See Gardner, supra note 20, at 348. Alternatively, she hypothesizes that the behavior functions as an informal means of socializing men to rejection by women. See id. at 348-49.

126 See supra p. 536.

${ }^{127}$ A complete analysis of all the First Amendment issues involved in the regulation of various types of speech and conduct included in street harassment is beyond the scope of this Article. By simply sketching, in broad terms, some of the ways in which I believe that regulation of street harassment can withstand scrutiny under the First Amendment, I do not mean to reflect disrespect for the important values embodied in that Amendment, but merely to open up discussion of the conflicting interests and values involved. 
assault or the intentional infliction of emotional distress (the intent of fifteen percent of the respondents in Benard and Schlaffer's study) is not protected by the First Amendment and can therefore be regulated. 128

Second, the speech involved in street harassment often falls within established exceptions to the First Amendment. In some cases - if a harasser shouts "You whore" at a woman in the presence of an overhearing passerby, for example - the harassment may constitute defamation. ${ }^{129}$ In other cases, street harassment may constitute obscenity, or it may be regulated as "fighting words," a category that I discuss in some detail below. ${ }^{130}$ Street harassment is similar, moreover, to types of harassment that are already regulated without constitutional difficulty. For example, it may be compared to verbal sexual harassment in the workplace that falls under Title VII.131 Regulation of sexual harassment in the workplace has been described as falling within the "captive audience" exception to the First Amendment. ${ }^{132}$ Power relationships in the workplace are based both upon institutional hierarchies and upon economic coercion: a woman is not genuinely free to leave unless she is indifferent to the loss of wages and possible impact upon her career. ${ }^{133}$ This same reasoning can extend to the harassment of women in the street, where women are also required to be present in order to reach places necessary to their lives, including their places of employment, and where power is ex-

128 As Professor Schauer has pointed out, this is true of many other types of speech as well: perjury, extortion, threats, false warranties, and conspiracies to fix prices, to name a few. See Frederick Schauer, Categories and the First Amendment: A Play in Three Acts, 34 Vand. L. REV. 265, 270-7I (x98I). We exclude antitrust law, securities regulations, and contract law from the scrutiny of the First Amendment as a matter of course, "because they have nothing to do with what the concept of free speech is all about." Id. at 274.

${ }^{129}$ Accusing a woman of unchastity has traditionally been regarded as actionable without proof of damages under the law of defamation. See W. PAGE KeEton, DAN B. DobBS, RoBert E. Keeton \& David G. Owen, Prosser and KeEton on the Law of Torts § I12, at 79293 (5th ed. I984).

${ }^{130}$ See infra pp. 558-63.

131 See 29 C.F.R. \& I604.II(a) (I992) (including "verbal . . . conduct of a sexual nature" as one possible form of sexual harassment under Title VII).

132 The captive audience doctrine refers to speech that is forced upon an unwilling listener, thus bringing the listener's right to privacy into conflict with the speaker's right to speech. See, e.g., Marcy Strauss, Sexist Speech in the Workplace, 25 HARv. C.R.-C.L. L. REv. I, 12-13 (1990). This is, of course, not the only ground upon which Title VII restrictions on verbal sexual harassment have been upheld under the First Amendment. See, e.g., Robinson v. Jacksonville Shipyards, 760 F. Supp. 1486, 1536-37 (M.D. Fla. 1991) (upholding restrictions upon speech (including pornography) in the workplace as permissible time, place, and manner restrictions).

133 Not only is freedom to exit a myth if one is dependent upon wages, but women are likely to stay rather than to leave an abusive situation for other reasons as well. See Martha R. Mahoney, Exit: Power and the Idea of Leaving in Love, Work, and the Confirmation Hearings, 65 S. CAL. L. REV. 1283, 1294-95, 1300-04 (1992). 
ercised against them in such a manner as to restrict their liberty. ${ }^{134}$ Whether to give women "equal opportunity" to use the public streets, or because they are in fact "captive" when they must use those streets, ${ }^{135}$ regulation of street harassment should be upheld. ${ }^{136}$

Third, street harassment is a good example of what is sometimes called "low-value speech" and is thus subject to minimal scrutiny under the First Amendment. 137 Low-value speech may include the following: (I) speech that is far afield from the central concern of the First Amendment - the effective popular control of public affairs; ${ }^{138}$ (2) speech that has purely noncognitive appeal; ${ }^{139}$ and (3) speech that is not intended to communicate a substantive message. ${ }^{140}$ Additionally, judicial scrutiny is more deferential in areas in which the "government is unlikely to be acting for constitutionally impermissible reasons or producing constitutionally troublesome harms."141

To the extent that protection of discourse on public issues is at the core of the First Amendment, ${ }^{142}$ the speech elements in street harassment do not implicate those values. There is no way to interpret

${ }^{134}$ See supra pp. 520-21; infra pp. 541-42.

${ }^{135}$ In discussing the captive audience doctrine, Professor Haiman would distinguish between "situations in which the target of a communication is physically free to escape from its continuation and those in which the target is physically captive," but recognizes as one example of "captivity" the situation where a target is "on a bus which he must ride to work." Franklyn S. Haiman, Speech v. Privacy: Is There a Right Not to Be Spoken To?, 67 Nw. U. L. Rev. I53, I94 (I972). Although Haiman's distinction would not work for women who are pedestrians, it does cover the public transportation context - one in which harassment is a considerable problem - and there is no inherent reason why its logic should not be extended to the streets women must traverse on their way to work, school, and other locations necessary to their daily lives.

${ }^{136}$ Speech is also regulated and/or prohibited in a variety of other contexts involving harassment. For example, orders of protection entered in domestic violence cases frequently prohibit the defendant from contacting the plaintiff even by telephone, based upon past incidents of harassment or violence (and thus upon a continuing, though implicit, threat of violence). For example, the Illinois Domestic Violence Act of 1986 , which authorizes the issuance of orders of protection in cases of domestic violence, includes "repeatedly telephoning petitioner's place of employment, home, or residence" within the definition of prohibited harassment. ILL. ANN. StaT. ch. 40, II 23 I I-3(6)(ii) (Smith-Hurd Supp. 1992).

137 See, e.g., Cass R. Sunstein, Pornography and the First Amendment, I986 DUKE L.J. 589, 602-08 (describing the distinction between low-value and high-value speech).

138 See id. at 603 (citing Bethel Sch. Dist. No. 403 v. Fraser, 478 U.S. 675, 685-86 (1986)).

139 See id. (citing Frederick Schauer, Speech and "Speech" - Obscenity and "Obscenity": An Exercise in the Interpretation of Constitutional Language, 67 GEo. L.J. 899, 932 (I979); and Chaplinsky v. New Hampshire, 3I5 U.S. 568, 57I-72 (1942)).

140 See id. at 603-04.

141 Id. at 604; see also id. at $604 \mathrm{n} .90$ (contrasting the strict judicial scrutiny applied to the internment of Japanese-Americans in Korematsu v. United States, 323 U.S. 214, 216 (1944), with the intermediate scrutiny applied to the gender-based drinking age in Craig v. Boren, 429 U.S. I90, 197 (1976)).

142 See, e.g., Boos v. Barry, 485 U.S. 3I2, 3I8 (I988); Dun \& Bradstreet, Inc. v. Greenmoss Builders, 472 U.S. 749, 758-59 (1985); Connick v. Myers, 46I U.S. 138, 145 (1983). 
expressions such as "great tits" or "fuck you" in a one-on-one interaction between strangers as political comments that contribute directly or indirectly to the general discourse about public affairs; these comments are nothing more than "psychic assaults."143 Moreover, street harassers do not attempt to impart a cognitive message or intend to begin a dialogue with their victims. In such a case, as Professor Laurence Tribe has written, "[i]t is not plausible to uphold the right to use words as projectiles where no exchange of views is involved."144 Under these circumstances, "more speech" is unlikely to provide a remedy and may, indeed, exacerbate an encounter already laden with a potential for violence. Finally, even if subjected to strict scrutiny under the First Amendment, the regulation of street harassment should pass muster, in my opinion, because it is essential to compelling state interests unrelated to the suppression of free expression: ${ }^{145}$ the security, liberty, and equality of women. ${ }^{146}$

I am convinced that the protection of these compelling interests can be accomplished without violence to the First Amendment. Nonetheless, the Supreme Court might still strike down a street harassment regulation under its 1992 decision in R.A.V. v. City of St. Paul. ${ }^{147}$ R.A.V. involved a white youth who burned a cross on the lawn of a Black family. The city of St. Paul prosecuted the youth under its hate crimes ordinance, which prohibited symbolic expression that "one knows or has reason to know arouses anger, alarm or resentment in others on the basis of race, color, creed, religion or gender."148 The Supreme Court struck down the ordinance as content-based and thus presumptively invalid on its face under the First Amendment. Al-

143 See Kent Greenawalt, Insults and Epithets: Are They Protected Speech?, 42 RuTGers L. REV. 287, 293 (I990) (comparing such insults to "slaps or pinches," and arguing that their abusive character "diminishes the expressive importance of the words").

144 Laurence H. Tribe, american Constitutional Law $\S 12-8$, at 837 (2d ed. 1988).

145 See, e.g., United States v. O'Brien, 39y U.S. 367, 377 (1968). Any particular regulation, of course, would also have to be reviewed to determine whether the incidental restriction on speech was no greater than essential to the furtherance of this governmental interest - an inquiry that cannot be undertaken in the abstract. See id.

146 The right to free expression in a public forum is not absolute and can be restricted on the basis of content only if "its regulation is necessary to serve a compelling state interest and . . . is narrowly drawn to achieve that end." Frisby v. Schultz, 487 U.S. 474, 48r (1988) (quoting Perry Educ. Ass'n v. Perry Local Educators' Ass'n, 460 U.S. 37, 45 (1983)); accord Roberts v. United States Jaycees, 468 U.S. 609, 623 (1984). Thus, the government's compelling interest in eliminating all forms of discrimination against women, see Board of Directors of Rotary Int'l v. Rotary Club, 48I U.S. 537, 549 (1987); Roberts, 468 U.S. at 623-24, can justify interference with First Amendment rights, see New York State Club Ass'n v. City of New York, 487 U.S. I, I2 (1988); Rotary Int'l, 48I U.S. at 549; Roberts, 468 U.S. at 623; see also Pittsburgh Press Co. v. Pittsburgh Comm'n on Human Relations, 413 U.S. 376, 39I (1973) (upholding an ordinance that prohibited newspapers from printing sex-segregated "help wanted" ads).

147 II2 S. Ct. 2538 (I992).

148 St. PaUl, Minn., Legis. CODE $§ 292.02$ (I990), cited in R.A.V., II2 S. Ct. at 254 I. 
though St. Paul could ban all fighting words, it could not, according to the Supreme Court, "regulate use based on hostility - or favoritism - towards the underlying message expressed."149 Many may argue that street harassment prohibitions would by necessity be contentbased. As Justice Stevens noted in his concurrence in R.A.V., however, all of First Amendment jurisprudence is content-based to some extent. 150

Indeed, as the concurring Justices agreed, the majority opinion in R.A.V. is so inconsistent with "well-settled principles of First Amendment law," which entitle fighting words to little, if any, First Amendment protection, ${ }^{151}$ that it is difficult to predict the outcome of cases that may arise in different contexts. ${ }^{152}$ A street harassment ordinance might, for example, fall under R.A.V.'s exception for content-based regulation when "the basis for the content discrimination consists entirely of the very reason the entire class of speech at issue is proscribable."153 Moreover, the R.A.V. Court conceded that the use of Title VII to prohibit sexually derogatory fighting words in the employment context would survive First Amendment scrutiny. ${ }^{154}$ Regulation of street harassment - that is, regulation of virtually identical speech in a different context - could be upheld on the same grounds. Additionally, street harassment might be prohibited as "fighting words that are directed at certain persons or groups"155 — or perhaps as "threats of violence [which] are outside the First Amendment"156 both of which the R.A.V. Court recognized as facially valid classifications under the First Amendment. Yet the Court struck down the St. Paul hate-crimes ordinance, even though these acknowledged exceptions seemed to apply with equal force in the context of that case. ${ }^{157}$

149 R.A.V., II2 S. Ct. at 2545 .

${ }^{150} \mathrm{See}$ id. at 2563 (Stevens, J., concurring in the judgment) (arguing that "our entire First Amendment jurisprudence creates a regime based on the content of speech").

151 Id.

152 I obviously think that $R . A . V$. was wrongly decided, but I refrain from any more extended critique of the opinion here. I am certain that the law reviews will contain detailed and ample discussion of R.A.V. See, e.g., Akhil Reed Amar, The Supreme Court, I9gI Term-Comment: The Case of the Missing Amendments: R.A.V. v. City of St. Paul, Io6 HARv. L. REv. 24 (I992).

153 R.A.V., II2 S. Ct. at 2545 . For example, the majority concluded that the federal government may prohibit only threats of violence directed against the President "since the reasons why threats of violence are outside the First Amendment . . . have special force when applied to the person of the President." Id. at 2546.

154 Id. at 2546.

$155 \mathrm{Id}$. at 2548 .

$156 \mathrm{Id}$. at 2546.

157 Not only are racial groups protected under Title VII, but, as "discrete and insular minorities," they may also be entitled to "a more searching judicial inquiry" than is applied in cases of discrimination against women. $C f$. United States v. Carolene Prods. Co., 304 U.S. 
The specific provisions of a regulation that governs the harassment of women on the street will obviously be relevant to any constitutional challenge. Nonetheless, the outcome of such a challenge will depend primarily upon whether the majority of the Supreme Court deems regulation of street harassment to be more analogous to regulation of verbal sexual harassment in the workplace than to the St. Paul hate crimes ordinance it struck down in R.A.V. After R.A.V., it appears that the current Supreme Court would be inclined to strike down any such regulation as gender-based, content-based, or underbroad. Yet the First Amendment does not require this result. Indeed, prevention of the intimidation of women citizens by street harassment can in fact further the goals of the First Amendment, by allowing women to participate freely in the public arena and add their voices to the community debate. ${ }^{158}$

\section{If There Were a Will, Is There a Way? The TREaTMENT OF STREet Harassment UNDER CURRENT LAW}

Many potential legal remedies exist for the behaviors I have described as street harassment. For example, women have sought criminal prosecution, either for assault or under existing criminal statutes against harassment, the use of abusive or obscene language on the streets, or "fighting words." A criminal law approach has a number of advantages, including the provision of a free attorney by the state and the imprimatur of collective disapproval of the prohibited conduct. On the other hand, criminal remedies generally do not provide compensation in the form of damages, and damage judgments, if large enough, may have a greater deterrent effect than criminal prosecution alone. There are other practical disadvantages to a criminal law approach as well. The same personnel - police, state's attorneys, and judges - who have not always vigorously investigated, or prosecuted, or even taken seriously, cases of sexual assault will be responsible for cases brought on behalf of targets of street harassment. Moreover, if history is any guide, the state may selectively and discriminatorily enforce these laws against poor people and minorities. ${ }^{159}$

\footnotetext{
144, I53 n.4 (1938) (noting that discrimination against "discrete and insular minorities" may warrant a higher degree of scrutiny).

158 Cf. Catharine A. MacKinnon, Francis Biddle's Sister: Pornography, Civil Rights, and Speech, in FEMINISM UNMODIFIED I63, I95 (1987) (arguing that restrictions on pornography will help women gain the "affirmative access to speech" that has been denied them).

${ }^{159}$ See, e.g., Lawrence Sherman, Janell D. Schmidt, Dennis P. Rogan, Douglas A. Smith, Patrick R. Garten, Ellen G. Cohn, Dean J. Collins \& Anthony R. Bacich, The Variable Effects of Arrest on Criminal Careers: The Milwaukee Domestic Violence Experiment, 83 J. Crim. L. \& CRIMINOLOGY I37, I4I-42 (1992) (arguing that police exercise their discretion in making arrests and tend to arrest those who strike them as "riffraff").
} 
For these reasons, women may be reluctant to press charges in criminal court.

Women have also sought legal recourse for street harassment under a number of civil law rubrics, including the torts of assault, intentional infliction of emotional distress, and invasion of privacy. In this section, I describe the case law under each of these legal categories, both criminal and civil, beginning with those that have produced the most analogous precedents and proceeding to those that are more speculative but nonetheless encouraging. I also describe the variety of creative self-help remedies that women have employed, and discuss the successes and failures of each approach.

\section{A. Assault}

First, women have attempted to obtain redress for harassment by suing their harassers for assault. This approach has presented the following obstacles: (I) a history of bias against women not deemed by the court to be "of good character" (a judgment often influenced by race and class); (2) discriminatory enforcement against harassers who are Black or poor; (3) an intent requirement; (4) a requirement in some jurisdictions that the defendant have had a present capacity to inflict harm; (5) judicial reluctance to impose liability for "mere words"; (6) a requirement that the plaintiff's fear have been objectively reasonable, measured by the reactions of the reasonable man; and (7) a tendency to require that the harasser's behavior have been repetitive. Nonetheless, many street harassment situations do resemble assaults more than any other legal category, and efforts to press this identification upon the legal system should not be abandoned.

Criminal assault is commonly defined as follows:

A person commits an assault when, without lawful authority, he engages in conduct which places another in reasonable apprehension of receiving a battery. 160

One may also sue for assault as a civil law tort:

An actor is subject to liability to another for assault if

(a) he acts intending to cause a harmful or offensive contact with the person of the other or a third person, or an imminent apprehension of such a contact, and

(b) the other is thereby put in such imminent apprehension. ${ }^{161}$

On its face, a charge of assault appears to have a lot of promise, particularly because it so closely matches the accounts women give of the fear that harassment arouses in them. Moreover, the concept of

160 ILl. REV. STAT. ch. 38, I I2-I (1979).

161 Restatement (SECOND) OF TORTS \& 2I (1965). 
assault not only captures the fear of rape, which underlies many women's responses to harassment, but also embodies the liberal values of freedom and mobility, which harassment restricts. As one court stated in upholding an assault conviction for street harassment:

The public streets and sidewalks belong to all alike. This schoolgirl had a right to go anywhere on these streets, and no one, white or black, had any right to intentionally block her way and turn her from the course she was going, by actual force or by such language and show of violence that would put her in fear and make her afraid to go, or make her turn back and go some other way, on account of such language . . . ${ }^{162}$

Assault, in this interpretation, is thus the polar opposite of liberty.

Some women have succeeded in fitting their experiences of harassment into the mold of assault, both criminal and civil. These successes, however, were grounded in an ideology of gender inequality and protection for the "weaker" and "more delicate" sex - at least when the woman accosted was either a virgin or married. In I895, for example, one Texas court upheld a civil damage award for "assault with intent to have carnal knowledge" in a case in which a married woman was propositioned by her husband's uncle, because:

It is too plain for argument, we think, that a willful violator of woman's most sacred right of personal security, such as the verdict finds plaintiff in error to have been, though her body be not touched except by his foul breath and speech, should respond in damages for an outrage to her feelings which proceeds so directly from his concurrent criminal purpose and act. ${ }^{163}$

Plaintiffs proceeding on both criminal and civil assault actions also face the courts' historical unwillingness to recognize harms if the plaintiffs do not fit the gender stereotype of chastity. For example, within three years of the case just described, another Texas court overturned the criminal assault conviction of a defendant who had made indecent propositions to a woman after overtaking her on horseback on a public road. ${ }^{164}$ The court reversed because it concluded that the woman was unchaste and thus the defendant had "reason to believe that she would permit him to copulate with her, or, at least,

162 State v. Williams, I20 S.E. 224,227 (N.C. 1923). The "show of violence" involved in Williams was a repeated proposition ("Give me some of your _ـ, in the court's transcription) directed by a Black man to a white girl. See id. at 225; see also State v. Allen, 95 S.E.2d 526, 528 (N.C. I956) (noting that "no man by the show of violence has a right to put another in fear and thereby force him to leave a place where he has the right to be" (citing State v. Daniel, 48 S.E. 544,545 (N.C. 1904$))$ ).

163 Leach v. Leach, 33 S.W. 703, 703 (Tex. Civ. App. 1895).

164 See Shields v. State, 44 S.W. 844, 844 (Tex. Crim. App. 1898). 
would not become offended at his proposition in that regard."165 Although presented in terms of the defendant's reasonable belief and thus, presumably, his intent, it is clear that the case turned on the court's view of the woman's moral character. As in rape prosecutions, a woman appears likely to succeed on an assault claim for harassment only if she is married, "chaste," or "of good character." This practical requirement is not confined to nineteenth-century cases. ${ }^{166}$

Catharine MacKinnon has suggested that "[c]ontemporary sexual mores make it difficult to imagine such cases in court" today ${ }^{167}$ and that women may not wish to revive a line of decisions that turn on a moralistic and puritanical approach to sex. ${ }^{168}$ It is important to distinguish, however, between the image of woman that appears in early cases - an unearthly, delicate creature upon a pedestal - and the reality that women, no matter how competent and powerful in their daily lives, are still vulnerable to rape and need the protection of the state against this and other forms of violence. It would be unwise to abandon the powerful categories of the common law because of the archaic images used in prior cases. Only by adapting these categories to address the reality of women's experiences can women surmount the common law's historical sexism.

The case law reveals some dangers, however, in applying the law of assault to street harassment. First, criminal remedies for street harassment may be enforced in a selective and racially discriminatory fashion. Some of the assault cases from the first half of this century were decided upon openly racist grounds. In a I923 case, for example, the North Carolina Supreme Court upheld the assault conviction of a Black man who harassed a fifteen-year-old white girl on the street, stating that "[a] negro man, using this foul indecent language towards a young white girl, as a matter of common knowledge, would create apprehension and fear."169 In short, the court held that a jury was entitled to assume that a white woman will react with fear to harassment by a Black man. By contrast, courts are likely to conclude that a white man - at least, a middle-class white man - is honestly (and thus innocently) mistaken if he believes that a Black woman on the street is a prostitute and therefore unlikely to be offended or alarmed

165 Id. at 844.

166 See, e.g., State v. McIver, 56 S.E.2d 604, 604 (N.C. 1949) (describing the victim as a woman "of good character"). This fact, of course, is something shared in common with prosecutions for rape, in which jurors are unlikely to believe that "a defendant is guilty if the victim had engaged in sex outside of marriage." Morrison Torrey, When Will We Be Believed?: Rape Myths and the Idea of a Fair Trial in Rape Prosecutions, 24 U.C. DAvis L. Rev. I013, I054 (1991).

167 MACKInNoN, supra note 2, at 166.

168 See id. at $172-73$.

${ }^{169}$ State v. Williams, I20 S.E. 224, 228 (N.C. I923); see also McIver, 56 S.E.2d at 604 (describing the victim as a "white woman of good character" accosted by a "colored man"). 
by an indecent proposal. ${ }^{170}$ This conclusion reflects the slave-era mentality about the general sexual availability of African-American women discussed above. ${ }^{171}$ In short, women must overcome the sexism and racism in the legal category of assault if we are to employ it effectively to combat harassment of women on the street.

Second, the standard elements of the law of assault may pose problems in their application to street harassment. Both the crime and tort of assault require a finding of intent, for example, that the harasser intended "to cause a harmful or offensive contact . . . or an imminent apprehension of such a contact."172 If Benard and Schlaffer's research is any indication, most men who harass women on the street deny any hostile intent and instead claim they were just having fun or intended their remarks as a compliment. ${ }^{173}$ Only fifteen percent of the men surveyed by Benard and Schlaffer admitted that their intent was to anger or humiliate the woman, ${ }^{174}$ a response they probably would not give so freely on the stand. Thus, unless the content or context of the street harassment itself reveals an intent to cause fear of an offensive contact, a harasser would probably go unpunished.

Moreover, in many jurisdictions, an action for criminal assault requires that the assailant have had the present capacity to inflict the injury feared. In a 1985 Georgia case, for example, four motorcyclists at a gas station propositioned four women customers in extremely obscene language and, when asked by the female station attendant to leave, verbally abused and threatened her. ${ }^{175}$ However, because the attendant was inside the station and seventy feet away from the bikers when the conduct occurred, the appellate court overturned the bikers' assault convictions. ${ }^{176}$ Thus, in states that require "present capacity," an assault charge against a construction worker on a scaffold would most likely fail.

In addition, many courts faced with a suit for assault are reluctant to impose liability for "mere words" or "mere solicitation,"177 the point of view that led Calvert Magruder to make his infamous remark that "there is no harm in asking."178 Other courts have analogized the "mere words" situation to that of a prostitute soliciting customers and

\footnotetext{
170 See infra p. 556 .

171 See supra pp. 533-34.

172 Restatement (SECOND) OF TORTS § 2 I (1965).

173 See Benard \& Schlaffer, supra note $\mathrm{I}_{3}$, at $7 \mathrm{I}-72$.

174 See id. at 7 x.

175 See Hamby v. State, 328 S.E.2d 224, 225 (Ga. Ct. App. I985).

${ }^{176} \mathrm{See} i d$. at 226. The case was, however, remanded for resentencing under Georgia's fighting words statute. See id.

177 See, e.g., Reed v. Maley, 74 S.W. I079, I082 (Ky. I903); Prince v. Ridge, 66 N.Y.S. 454,455 (N.Y. Sup. Ct. r900).

178 Calvert Magruder, Mental and Emotional Disturbance in the Law of Torts, 49 HARV. L. REV. I033, I055 (1936).
} 
reasoned that there should not be liability in the one instance if there is not in the other. As one IgO3 court reasoned:

Suppose a bawd should solicit a man upon a public street to have sexual intimacy with her; he certainly could not maintain a civil action against her. If an action could be maintained by a woman against a man for such solicitation, the same right to maintain one would exist in his favor. ${ }^{179}$

Similar arguments, premised on the supposed justice of mirror-image remedies for men and women, are common today, especially in the context of the workplace, where the allegation is that men may also be the object of harassment. 180

Mirror-image arguments are flawed in both the context of the workplace ${ }^{181}$ and of the street. This is particularly clear in the suggested analogy between solicitation to prostitution and harassment of women on the street. The typical street harasser is not, in fact, making a good faith solicitation to sexual intercourse, even though his words may state that he is. A prostitute, on the other hand, is in fact soliciting intercourse, for pay, and there are criminal sanctions against her behavior. If men are bothered by such solicitation, they can call the police. The basis for an action for assault, by contrast, is the fear the harasser causes in his target, which is inextricably linked to the fact that in the vast majority of cases, men rape women, and not the other way around. Thus, when a prostitute solicits a man, he generally does not feel imminent apprehension of a harmful contact. Hence, he cannot satisfy the standard for assault. As such, it is both consistent and just that women be permitted to sue street harassers for assault, even though a man would be unable to bring a similar action against "a bawd upon a public street."

Mirror-image reasoning - evaluating the behavior of a woman as if she were a man (and vice versa) - can defeat street harassment suits in other ways. For example, an assault case may founder on the requirement that the victim's fear be "objectively" reasonable. To male judges or observers, street harassment may not seem intimidating. This is not surprising, because studies reveal that men perceive and interpret street harassment differently than do women. Women typically believe that targets of street harassment feel significantly less

179 Reed, 74 S.W. at 108r.

180 See, e.g., Lloyd R. Cohen, Sexual Harassment and the Law, SocIETY, May-June I99I, at $8,9-10$.

${ }^{181}$ In the workplace context, men and women are not similarly situated with respect either to the initiation of sexual interactions in our culture (which are normally initiated by men) or to power relationships in the workplace (where the man is usually the supervisor or superior). See GUTEK, supra note 2, at $3 \mathrm{r}$. When the case of a powerful woman who has sexually harassed a man in a subordinate position is presented, that case should be dealt with on its terms, not as a matter of rhetoric. 
safe than male respondents think they do. ${ }^{182}$ Thus, although the reasonable man may not be placed in apprehension of receiving a battery by a stranger yelling, "Hey, cunt," the response of a reasonable woman may differ, because of her constant awareness of the violent consequences of male hostility to women and her realistic fears of rape. Although only a minority of harassment incidents may lead to an "offensive touching," a reasonable woman cannot know which will be the one, and thus must regard every encounter as potentially dangerous. Therefore, a cause of action based on assault would address street harassment effectively only if it were combined with a reasonable woman standard - at least until that indeterminate date when men are able to see the world from a woman's point of view. ${ }^{183}$

Finally, courts and lawmakers have not generally taken criminal assault charges against street harassers seriously unless the harassment was repeated or obsessional in nature. For example, in State $v$. Allen, ${ }^{184}$ a North Carolina court convicted a defendant who, on three separate occasions, drove slowly beside his victim as she walked to work, staring at her and moving the lower part of his body back and forth. ${ }^{185}$ When harassment has a repeated or obsessional quality, such

182 See Jaclyn Packer, Sex Differences in the Perception of Street Harassment, 5 WOMEN \& Therapy 33I, 334 (I986). Female subjects also thought that women were significantly less complimented, less pleased, more angry, and more offended by street harassment than male survey respondents thought. See id. There is also evidence that men perceive friendliness from women as seduction, another misperception that may lead to inappropriate male behavior in some situations. See Antonia Abbey, Sex Differences in Attributions for Friendly Behavior: Do Males Misperceive Females' Friendliness?, 42 J. PERsonality \& Soc. Psychol. 830, 836 (1982); Frank Saal, Catherine Johnson \& Nancy Weber, Friendly or Sexy? It May Depend on Whom You Ask, r3 Psychol. Women Q. 263, 268 (1989).

183 The reasonable woman standard is increasingly being employed by courts in cases involving sexual harassment in the workplace. See, e.g., Ellison v. Brady, 924 F.2d 872, 87880 (gth Cir. 1991); Drinkwater v. Union Carbide Corp., 904 F.2d 853, 860 (3d Cir. 1990); King v. Board of Regents, 898 F.2d 533, 537 (7th Cir. 1990); Lipsett v. University of P.R., 864 F.2d $88 \mathrm{I}, 898$ (Ist Cir. I988). The standard has also been criticized as subject to an essentialist analysis that equates the reasonable woman's reactions with those of a middle-class, heterosexual, white woman. See, e.g., Martha Chamallas, Feminist Constructions of Objectivity: Multiple Perspectives in Sexual and Racial Harassment Litigation, I TEx. J. WoMEN \& L. 95, 103 (1992). Although care should be taken to avoid this restricted interpretation, it may still be important to the development of the law to allow the reasonable woman to push the reasonable man off the stage for a period before the reasonable victim takes over. The danger of adopting a reasonable victim standard too soon is that the reasonable victim may simply be a new name for the reasonable man, unless a course of litigation has first shown that his reactions can be quite different from those of the reasonable woman. I acknowledge the dangers of an essentialist interpretation of the reasonable woman standard in the meantime. Even if feminist attorneys take care not to fill in this new persona with the characteristics of white, middle-class women, there are not enough of us practicing law, and all of us are usually more interested in winning the individual plaintiff's case than in molding the categories of the common law.

18495 S.E.2d 526 (N.C. 1956 ).

$185 \mathrm{See}$ id. at 526-27. State v. Williams, 120 S.E. 224 (N.C. 1923), and State v. McIver, 56 S.E.2d 604 (N.C. I949), also involved repeated encounters. 
as the harassment of a movie star by an obsessed fan, the law steps in. ${ }^{186}$ This repetition requirement is a substantial obstacle in the typical street harassment case, in which harassers may repeat their conduct many times each day, even at the same location, but never direct it at the same woman twice.

In sum, a remedy based on assault, as assault has been interpreted in the case law thus far, fails in most instances to provide relief for street harassment, because it requires a finding both of intent on the part of the harasser and of an "objective" reasonableness of the woman's apprehension. In many states, moreover, the defendant must have had a "present capacity to inflict injury" and must have used "more than mere words"; courts often require repetition of the harassing conduct as well. For these reasons, as well as the history of sexist attitudes and racism associated with its use, the crime and tort of assault present many problems as a vehicle to redress the harms of street harassment.

\section{B. Statutes or Ordinances Prohibiting Harassment in Public Places}

A second approach to addressing street harassment is a criminal action under state statutes or municipal ordinances that prohibit harassment in a public place. Pennsylvania's harassment statute is fairly representative of this genre:

A person commits a summary offense when, with intent to harass, annoy or alarm another person:

(I) he strikes, shoves, kicks or otherwise subjects him to physical contact, or attempts or threatens to do the same; or

(2) he follows a person in or about a public place or places; or

(3) he engages in a course of conduct or repeatedly commits acts which alarm or seriously annoy such other person and which serve no legitimate purpose. ${ }^{187}$

Comparable harassment statutes exist in at least ten other states. ${ }^{188}$ These statutes, violations of which constitute a misdemeanor, have sometimes been used in cases involving the harassment of women in public places. They have significant drawbacks, however, specifically attributable to their intent and repetition requirements.

186 For a discussion of the legal remedies in cases involving obsessional harassment, see Comment, A Remedial Approach to Harassment, 70 VA. L. REv. 507 (1984); Linda M. Gunderson, Note, Criminal Penalties for Harassment, 9 PAC. L.J. 217 (1978).

187 I8 Pa. Cons. Stat. ANN. § 2709 (I972).

188 See Ala. Code § I3A-i I-8 (1975); AlaSka Stat. § ir.61.I20 (1989); ARK. Code ANN. § 5-7I-208 (Michie I987); Colo. REv. STAT. § I8-9-III (I986); DEL. CODE ANN. tit. II, § I3II (1974); Haw. Rev. STat. § 7II-I IO6 (Ig88); N.H. Rev. Stat. ANN. § 644:4 (Ig86); N.J. Rev. Stat. § 2C:33-4 (1978); N.Y. Penal Law § 240.25 (Consol. I984); OR. Rev. Stat. § I66.065 (I99I); MODEL PENAL CODE $§ 250.4$ (1962). 
First, these statutes require the state to prove that the harasser acted with "intent to harass, annoy or alarm."189 One New York criminal harassment case failed in large part because of this obstacle, as the court measured the defendant's conduct according to the reasonable man standard, in a transparently racist fashion. ${ }^{190}$ The defendant, Malausky, described by the court as a "lone white suburban male," backed his "expensive foreign car" along a curb at 3 a.m. and solicited three young African-American women, whom he apparently believed to be prostitutes. ${ }^{191}$ As noted above, African-American women have historically been plagued by the racist assumption that they are generally available for sexual gratification. ${ }^{192}$ Charges brought against Malausky under the New York harassment statute were dismissed, however, on the grounds that it was not Malausky's intent to annoy, but only to seek "female companionship."193 Thus, according to the court, although Malausky's behavior might seem to fall within the literal meaning of the statute, the court held that the statute must be construed as prohibiting only "language or conduct ... by its nature . . . of a sort that is a substantial interference with (our old friend) the reasonable man."'194 Apparently the reasonable man does not regard being solicited to prostitution if you happen to be Black and on the street at night as a "substantial interference." Apparently the reasonable man also does not bring criminal charges against white suburban males in expensive foreign cars - which leads one to question exactly whose "old friend" this reasonable man is. In sum, the application of a criminal harassment ordinance in Malausky shows the near impossibility of proving intent in such a case, the sexist fashion in which the reasonable man standard is likely to be applied by a mostly male judiciary, and the race and class bias that appear inevitable in the enforcement of such a statute.

As I have already discussed in connection with assault, the problems associated with proof of intent raise a substantial obstacle in most cases involving street harassment. ${ }^{195}$ Nonetheless, the intent requirement may pose a less serious problem in connection with establishing intent to harass or annoy than in assault cases, which require intent to place the victim in reasonable apprehension of an imminent battery. Many of the remarks that men direct at women

189 I8 Pa. Cons. Stat. ANN. § 2709 (I983).

190 See People v. Malausky, 485 N.Y.S.2d 925, 927-28 (Rochester City Ct. I985).

191 Id. at 927 .

192 See supra pp. 533-34.

${ }^{193} \mathrm{Id}$. at 928 . This is reminiscent of the court's treatment of the sexuality of the plaintiff, a woman solicited while on horseback, in Shields v. State, 44 S.W. 844,844 (Tex. Crim. App. 1898). See supra pp. 550-51.

194 Malausky, 485 N.Y.S.2d at 928 (quoting People v. Harvey, 123 N.E.2d 81, 83 (N.Y. I954)).

195 See supra p. 552. 
on the street contain evidence of their own intent. It would be difficult for anyone, even the reasonable man, to construe remarks such as "fucking bitch, fucking cunt,"196 "white whore,"197 or "you're just a piece of meat to me, bitch,"198 as not intended to harass, annoy, or alarm the person at whom they were directed.

Second, even if she were able to prove intent, a target of street harassment who prosecutes her claim under a typical harassment statute would also have to show that the harasser "engage[d] in a course of conduct or repeatedly committ[ed] acts which alarm or seriously annoy."199 The Malausky court held that "[o]ne brief conversation does not establish a course of conduct."200 Yet, as described above, any cause of action that requires repeated acts directed at the same woman is unlikely to offer an effective remedy against the typical incident of street harassment. ${ }^{201}$

There are very few reported cases that involve facts similar to the typical street harassment situation in which a conviction has been upheld under a more general, traditional harassment statute. ${ }^{202}$ In one such case, a stranger confronted and solicited oral sex from a female student at 3:30 a.m. in a semi-public place, a college dormitory lounge. ${ }^{203}$ The defendant was convicted under the Pennsylvania harassment statute, ${ }^{204}$ because the majority found that his conduct was "repeated" (he repeated his request); he was sentenced to pay a $\$$ Ioo fine, an obviously de minimis sentence. ${ }^{205}$ Moreover, the views of the dissenting judges in this case may reflect the opinion of the judiciary more realistically than do those of the majority, given the absence of other similar cases. Referring to the fact that women are frequently

\footnotetext{
196 Branda v. Sanford, 637 P.2d 1223, I224 (Nev. I98I) (The court's transcription reads: "f- $-\mathrm{k}-\mathrm{g}$ bitch,' 'f-k-g c-t.'").

197 Blair, supra note 24 , at II9.

198 Kannapell, supra note 30 , at 37.

199 I8 Pa. Cons. STat. ANN. § 2709 (1983); see supra p. 555.

200 People v. Malausky, 485 N.Y.S.2d 925, 929 (Rochester City Ct. 1985).

201 See supra pp. 554-55. These harassment statutes are most directly applicable to cases that involve obsessional harassment, in which one harasser stalks his victim over a period of time. See Comment, supra note 186, at 525; Gunderson, Note, supra note 186, at 238-39.

202 The lack of cases may reflect the failure of police and prosecutors to enforce harassment laws. It is also possible that women or their harassers have not appealed trial court dispositions. My research would not have revealed success and failure at the trial court level alone. Because these charges are brought as misdemeanors, it would not usually be considered worth the time and money to appeal a conviction, as was done to appeal the \$10o fine imposed in Commonwealth v. Duncan, 363 A.2d 803, 804-05 (Pa. Super. Ct. 1976).

203 See id. at 805. The female student had fallen asleep while studying; when she awoke, the defendant, a non-student and stranger, "was on a hassock in front of her, with his face in close proximity to her face. Appellant then requested a favor of Miss Hartman, saying, 'I never ate a pussy before." He repeated his request for a "favor," despite her repeated requests that he leave. Id.
}

204 I8 Pa. Cons. Stat. ANN. $\$ 2709$ (1983); see supra p. 555.

205 See Duncan, 363 A.2d at 805. 
annoyed by catcalls and sexual suggestions, one dissenter explicitly stated that a mere indecent request was insufficient to come within the statute. ${ }^{206}$ Furthermore, he opined, it would be unwise to criminalize such behavior because:

(I) the state runs the risk of criminalizing generally accepted behavior, leaving the actor without reasonable notice that his conduct is criminal; (2) such incidents are too frequent for a justice system to handle them efficiently; (3) courts cannot be expected to arbitrate what are frequently personal disputes by use of the criminal process. ${ }^{207}$

Thus, in this judge's view, street harassment should not be prosecuted under criminal statutes precisely because it is so widespread, frequent, and generally accepted, and thus difficult for the court system to handle. ${ }^{208}$ This view reflects society's more general failure to perceive incidents of harassment as non-trivial, in part because they are so pervasive. ${ }^{209}$

In sum, the current criminal harassment statutes are inadequate to address the typical incident of street harassment because they focus on the harasser's intent, they require repeated conduct, and they are usually interpreted by the judiciary as not extending to the problem of street harassment. Thus, the legal category that at first glance seems the most obvious remedy for street harassment is actually practically useless, at least in its current form. Clearly, we need to amend these statutes or write new ones - and to get many more women into the judiciary as well.

\section{Prosecution of Street Harassment as "Fighting Words"}

"Fighting words" statutes provide another vehicle for prosecution of street harassment. These statutes prohibit the use of abusive lan-

206 See id. at 8ro (Hoffman, J., dissenting). Judge Hoffman opined that the woman in this case was never really placed in apprehension for her safety (despite the fact that the remarks described were addressed to her by a stranger in the middle of the night with no one else present). See id. He also wondered whether "[g]iven society's increasing sexual permissiveness ... the suggested act is still considered 'indecent." Id. at 8ro n.7.

207 Id. at 809 n.4.

208 As Catharine MacKinnon has noted, when courts are confronted with a massive social problem that has been ignored, their first response is usually concern that the flood of complaints will be administratively difficult for the court system. See MacKinnon, supra note 2, at 9597 .

209 Moreover, as Catharine MacKinnon has pointed out in the context of sexual harassment in the workplace, the court uses the epithet "personal" in this case (in which a young woman was accosted by a stranger asking her for oral sex in the middle of the nightl) as a way to rationalize legal noninvolvement by treating harassment as an individual or isolated experience rather than the common and shared experience of women. See id. at 83-87. 
guage that tends to incite a breach of the peace. ${ }^{210}$ Georgia's statute provides a good example:

A person who commits any of the following acts commits a misdemeanor:

(I) Without provocation, uses to or of another, in his presence, opprobrious or abusive words which by their very utterance tend to incite to an immediate breach of the peace, that is to say, words which as a matter of common knowledge and under ordinary circumstances will, when used to or of another person in his presence, naturally tend to provoke violent resentment, that is, words commonly called "fighting words". ...211

Whereas the harassment statutes described above focus on the harasser's actions, these statutes focus on the target's likely reactions, specifically, whether the words used are likely to provoke the hearer to violence and thus a breach of the peace. ${ }^{212}$ Many fighting words statutes were originally intended as "anti-duelling" statutes. ${ }^{213}$

The Supreme Court has upheld against First Amendment challenges statutes that prohibit speech that has a tendency to provoke a breach of the peace. The classic definition of fighting words is words "which by their very utterance inflict injury or tend to incite an immediate breach of the peace." 14 In Chaplinsky v. New Hampshire,

210 In some states, there are also statutes that prohibit the use of obscene or insulting language on the streets; the Michigan Penal Code explicitly prohibits the use of any such language in the presence or hearing of a woman or child. See Mrch. CoMp. LAws ANN. $\$ 750.337$ (West I99I). Similar behavior may also be prohibited as a public nuisance. For example, Chicago's municipal code provides that:

Any person who shall commit any indecent, lewd, or filthy act in any public place in the city; who shall utter any lewd or filthy words ... or use any threatening or abusive language in the hearing of other persons; who shall make any obscene gesture in the presence of other persons; or, who shall make any overture of lewdness, tending to pervert the morals of any person, upon or in the public ways or other public place or in any public conveyance in the city, is hereby declared to be a common nuisance and shall be fined not to exceed $\$ 200.00$ for each offense.

ChICAGo, ILL., MUN. CODE $§ 8-8-070$ (I990). I have excluded these statutes from more extended analysis as potential street harassment remedies because they target an issue that is quite different from street harassment, one that is not necessarily problematic for women, who themselves may want the right to use some obscene words and phrases on the streets. Moreover, use of obscenity laws to fight street harassment could simply exacerbate the courts' continuing failure to perceive the differences between the harms of pornography and of obscenity. See generally MAcKinNon, supra note 158, at I74-75 (distinguishing between obscenity law, as a judgment about morality, and pornography, as a practice that harms women).

211 GA. CODE ANN. \& I6-II-39 (r992).

212 In this respect, fighting words statutes differ as well from disorderly conduct ordinances, which are directed at breaches of the peace resulting from the "disorderly" action of the offender, whereas fighting words statutes look to whether the reaction of the hearer, not of the defendant, is likely to breach the peace.

213 See Magruder, supra note 178 , at ro54.

214 Chaplinsky v. New Hampshire, 315 U.S. 568, 572 (1942). The words at issue in Chaplinsky were "damned Fascist" and "damned racketeer." Although the Supreme Court has never 
the Supreme Court declared that such words are offensive, not because of their actual impact on the particular addressee, but by their inherent nature:

The test is what men of common intelligence would understand would be words likely to cause an average addressee to fight. . . . The English language has a number of words and expressions which by general consent are 'fighting words' when said without a disarming smile. . . . Such words, as ordinary men know, are likely to cause a fight. So are threatening, profane or obscene revilings. ${ }^{215}$

The Court further refined this definition in Cohen $v$. California ${ }^{216}$ and limited it to personally abusive epithets directed face-to-face to the hearer, thus excluding communications that contribute to public discourse. ${ }^{217}$ This limitation leads Professor Tribe to conclude that "[t]he overriding idea in Chaplinsky is thus the isolation of those 'utterances [that] are no essential part of any exposition of ideas [and] of . . . slight social value as a step to truth,"' which are thus outside the core values protected by the First Amendment. ${ }^{218}$

Based on these descriptions, fighting words statutes seem to offer an appropriate remedy for many kinds of street harassment: they encompass personal, face-to-face insults that cannot possibly be described as political discourse; they apply to "threatening, profane or obscene revilings"; and they turn upon the reaction of the hearer rather than upon the intent of the speaker or harasser. And women have in fact obtained convictions in street harassment cases under the Georgia fighting words statute. ${ }^{219}$

Unfortunately, the fighting words standard, as it has been interpreted thus far, is based upon a male stereotype; it presupposes an encounter between two persons of relatively equal power who have

upheld a fighting words conviction based on Chaplinsky, it reaffirmed Chaplinsky in R.A.V. v. City of St. Paul, II2 S. Ct. 2538, 2543-44 (I992). In R.A.V., however, the Court held that fighting words statutes violate the First Amendment if they are content-based. See id. at 254849; supra pp. 546-48.

215 Chaplinsky, 315 U.S. at 573 (quoting State v. Chaplinsky, 18 A.2d 754, 762 (N.H. 194r)). $2164^{1} 3$ U.S. 15 (1971).

217 See id. at 20 (overturning a conviction for wearing a jacket with the words "Fuck the draft" written on it in a courthouse corridor, which was found to be a political comment not intended as a personal insult to any viewer).

218 TRIBE, supra note I44, $\$$ I2-8, at 839 (quoting Chaplinsky, 315 U.S. at 571-72).

219 See, e.g., Breaux v. State, r97 S.E.2d 695, 696-97 (Ga. 1973) (affirming the conviction, under a predecessor of Georgia's current fighting words statute, of a male driver who asked an I I-year-old girl pedestrian, "Have you ever been laid?"). But see Rozier v. State, 23I S.E.2d I3I, I3I (Ga. Ct. App. I976) (overturning the conviction of a defendant who remarked to a I6-year-old while she was at home with her five-year-old brother, "How about some pussy?" on the ground that the phrase did not constitute fighting words). This is also the statute under which the Hamby case, involving the motorcyclists at the gas station, was remanded. See supra p. $55^{2}$. 
been socialized to respond to insults with violence. ${ }^{220}$ Although men may react to abusive language by engaging in a physical fight, women are neither socialized to fight in general nor secure enough - for good reason - to do so in a street harassment situation. Far from fighting back, the average female target of street harassment is likely to react with fear, to freeze, and to pretend to ignore what is happening to her. ${ }^{221}$ Even if one interprets the fighting words standard as reflecting an underlying concern with the emotional distress that the words cause rather than as merely a means of keeping the peace, the assumption that outrage and injury is proved by evidence of violent reaction simply does not fit women's typical response to psychic injury. Women thus face serious obstacles in using fighting words statutes to obtain legal redress for street harassment.

One case decided under the Georgia law demonstrates the problematic nature of fighting words statutes in the context of street harassment. In Lamar $v$. Banks, ${ }^{222}$ a taxi driver picked up a female college student at the airport, drove her to an unfamiliar area, and tried to seduce her, saying, "I bet your honey doesn't have the nine and one-half inch penis I have."223 The woman ultimately escaped after giving him a fictitious address, and the driver was subsequently convicted under the fighting words statute. ${ }^{224}$ In response to his federal habeas petition, the Eleventh Circuit found that the words quoted were not inflammatory per se, but did note that the woman was essentially a "captive" of a strange male and that "the circumstances must have been alarming. . . . [S]ome women would have reacted violently." 225 Far from ending the inquiry, however, the court then remanded the case for an evidentiary hearing concerning the precise circumstances surrounding the use of those words in the specific case, to determine whether the driver's words in fact had a tendency to provoke his passenger to violence!226 In other words, the fighting words standard, as interpreted by the Lamar court, resulted in further proceedings to answer a nonsensical question. Why should it make a difference whether this or any woman would have been likely to respond with violence under these circumstances? Most

\footnotetext{
220 See Lawrence, supra note 82 , at $453-54$ (noting that this is a white male stereotype); Matsuda, supra note 10, at 2355; cf. Greenawalt, supra note 143, at 296-97 (suggesting that the degree of protection afforded by the First Amendment should depend on the speaker's knowledge of the inciting effect his words may have on his addressee). These commentators also note that it is more than a little strange to make a cause of action turn on the victim's propensity to react violently, leading Greenawalt to speak in favor of "equalization of victims." Id. at 297-99.

221 See supra p. 537.

222684 F.2d 7I4 (Irth Cir. I982).

223 Id. at 715 .

224 See id. at 715-16.

225 Id. at 7 I 9 .

226 See id. at 720.
} 
women would have done exactly what this woman did: attempted to escape from the situation by whatever stratagem seemed likely to prove successful. Given this reaction by a federal appellate court to a case that combined harassment with what was essentially a kidnapping and attempted rape, one cannot be sanguine about the prospect of a fighting words statute working more effectively in the typical street harassment situation, in which these exacerbating factors generally are not present, at least in the hands of judges who are not sensitive to the problem.

In fact, Chaplinsky mandates that fighting words be subjected to the purportedly objective test of whether "men of common intelligence would understand" them to be "likely to cause an average addressee to fight,"227 rather than to an inquiry into the reactions of a specific plaintiff. As with the reasonable man standard, ${ }^{228}$ women may have problems characterizing their reactions as those of the "man of common intelligence" or the "average addressee." This presents two discrete hurdles in the context of street harassment. First, the average man might not react to the harassing words with offense, alarm, or anger; to the contrary, he might claim to be flattered. ${ }^{229}$ Thus, unless a court bases its inquiry upon the probable reaction of the average woman to the language directed to her, a fighting words prosecution in the harassment context may flounder on the initial requirement of "offense." Second, the average woman may not react with violence but may instead fight back through other, less direct, means or may merely withdraw, defensively. Because the probable reaction of the average woman is not to fight, the prosecution will often fail on this second hurdle of "provocation." 230

Two other potential problems arise with the use of fighting words statutes. First, because the doctrine applies only to words, it may well be interpreted not to cover harassment that is non-verbal or otherwise inarticulate - wolf whistles, sucking noises, and catcalls, for example. Moreover, as has been pointed out in the context of racist speech, fighting words statutes fail effectively to address the real injury at issue, which is not the potential disruption of the peace, but, rather, the violation of the individual's sense of safety and wellbeing. ${ }^{231}$

227 Chaplinsky v. New Hampshire, 315 U.S. 568, 573 (I942) (quoting State v. Chaplinsky, I8 A.2d 754, 762 (N.H. I94I)).

228 See supra pp. 553-54; see also supra p. 556 (illustrating the race and class biases of the "reasonable man" standard).

${ }^{229}$ See Cohen, supra note 180 , at 8, 9; $c f$. GUTEK, supra note 2, at 68-69 (citing empirical studies that indicate that some male targets of sexual overtures concede that they may have encouraged the incidents).

230 For a discussion of potential problems with the "average addressee" test, see Greenawalt, cited above in note 143 , at $296-97$.

231 See, e.g., Nadine Strossen, Regulating Racist Speech on Campus: A Modest Proposal?, 1990 DUKE L.J. 484,5 II. 
Finally, and ironically in light of the Supreme Court's recent decision in R.A.V., ${ }^{232}$ courts may find problems of overbreadth when fighting words statutes are applied to street harassment. In the one case to reach the Supreme Court on this issue, the Court overturned the defendant's conviction on the grounds that the statute might implicate protected First Amendment expression. ${ }^{233}$ The two-paragraph per curiam decision does little justice to its subject, however, and was issued over the dissents of Chief Justice Burger and Justices Blackmun, Powell, and Rehnquist. Justices Powell and Rehnquist reasoned that the verbal assault in this case was menacing, insulting, and outside First Amendment protection. ${ }^{234}$

In short, the fighting words doctrine, as courts have thus far interpreted it, is male-biased in its central concept - the assumption that the harm of personally abusive language either consists in, or can be gauged by, its tendency to provoke a violent response. For this reason, its application by the courts has not provided women with an effective remedy for harassment. However, the doctrine contains within it a concept that has been hitherto undeveloped: the other "branch" of Chaplinsky, which allows the prohibition of words "which by their very utterance inflict injury."235 If women plaintiffs can establish that street harassment falls within this branch by explaining the injuries that the words inflict, as well as the reasons why they unlike men - are unlikely to fight back, the fighting words doctrine may hold more promise than any other legal standard. Alternatively, liberation of the traditional fighting words doctrine from the male stereotypes to which it has been linked and open recognition that women who are injured may not react by fighting back may result in a redefinition of "breach of the peace" to include infringement upon the safety and well-being of women. ${ }^{236}$

\section{Intentional Infliction of Emotional Distress}

Another potential remedy for street harassment is a tort suit for intentional infliction of emotional distress. The Restatement (Second) of Torts defines this tort as "extreme and outrageous conduct [that]

\footnotetext{
232 In his concurrence, Justice White describes the majority's opinion in R.A.V. as imposing a new "underbreadth" doctrine. See R.A.V. v. City of St. Paul, II2 S. Ct. 2538, 2553 (r992) (White, J., concurring). The concurrence, however, found the statute to be unconstitutional on traditional overbreadth grounds. See id. at 2558.

233 See Plummer v. City of Columbus, 4I4 U.S. 2, 2-3 (I973) (holding facially unconstitutional a statute that criminalized abusive language and reversing a conviction in a case involving the harassment of a female passenger by a taxi driver).

234 See id. at 3-4 (Powell J., dissenting).

235 Chaplinsky v. New Hampshire, 315 U.S. 568, 572 (I942).

236 The appointment and election of more women judges may hasten this interpretation of Chaplinsky, as would a campaign to educate the public and the predominantly male judicial and legal profession about the harms of street harassment.
} 
intentionally or recklessly causes severe emotional distress to another."237 This definition appears broad enough to encompass any number of wrongs, and women have looked to it to redress sexual harassment claims both in and out of the workplace. ${ }^{238}$ However, there are relatively few reported cases in which such an approach has succeeded in a context analogous to street harassment. ${ }^{239}$

In one case, a fifteen-year-old hotel busgirl brought suit against the actor Redd Foxx for both slander and intentional infliction of emotional distress after Foxx verbally accosted her with sexual innuendoes and then verbally abused her when she ignored his remarks. ${ }^{240}$ The trial court initially dismissed the case, but the Nevada Supreme Court reversed and remanded for a new trial. The proceedings on remand are not recorded.

If the Redd Foxx case was not settled on remand, the plaintiff would have had a fairly difficult burden to meet under the standard for intentional infliction of emotional distress. First, the tort requires proof of intent. I have already described the obstacles that proof of intent creates for targets of street harassment. ${ }^{241}$ Second, even if an

237 Restatement (SeCOND) OF TORTS § 46(I) (r965).

238 Intentional infliction of emotional distress claims are common as pendent claims in cases brought under Title VII for sexual harassment in the workplace. See, e.g., Stewart v. Thomas, 538 F. Supp. $89 \mathrm{I}, 896$ (D.D.C. I982) (sustaining an EEOC employee's tort claims against the individual defendant and Title VII "stressful workplace" claims against Clarence Thomas in his capacity as chairman on the ground that "the common law torts alleged . . . are distinct from the wrongs redressed by title VII"). Intentional infliction claims have also succeeded in surviving motions to dismiss in cases involving persistent harassment by telephone or mail. See, e.g., Mitran v. Williamson, I97 N.Y.S.2d 689 (N.Y. Sup. Ct. 1960) (holding that a jury could find the defendant liable for intentional infliction of emotional distress on the alleged facts that he solicited plaintiff and sent her obscene photos of himself in the mail); Samms v. Eccles, 358 P.2d 344 (Utah I96r) (reversing the dismissal of a claim of intentional infliction of emotional distress in a case in which the defendant was charged with persistent telephonic solicitation and one instance of indecent exposure).

239 Again, the lack of reported cases could mean either that no appeals have resulted from suits in which women have brought such charges, or that women have considered it futile to bring such cases. Given that this is a civil action, with a potential for contingent fee arrangements, one would assume that the decision whether to file suit has at least something to do with lawyers' assumptions about both the chance of success on such a claim and the potential for damages. If substantial damage awards had in fact resulted, one would expect to see reported appeals.

240 See Branda v. Sanford, 637 P.2d 1223 (Nev. 198I). Foxx asked the girl, whose name was Cheryl, if her name was "like in cherry," then yelled at her, among other things, that she was a "fucking bitch," and a "fucking cunt." He was also alleged to have said, "This is the one I want. This is her." Id. at 1224 .

${ }^{241}$ See supra p. 552. The Restatement does provide that liability for emotional distress may be based upon conduct that is caused recklessly as well as intentionally. See REstatEmENT (SECOND) OF TORTS $\$ 46(\mathrm{I})$ (I965). Although it might be easier to convince the finder of fact that the defendant knew or should have known that words such as those used by Redd Foxx would cause emotional distress, it would still be difficult to show that he acted in conscious disregard of that danger. 
intent to cause emotional distress can be inferred from the harasser's statements, the plaintiff must still show that his conduct was "extreme and outrageous." Indeed, as many have noted, the intentional infliction tort as a whole largely turns on the element of outrage. ${ }^{242}$

Commentators have also pointed to the circularity of the test for "outrageous" conduct. ${ }^{243}$ The Restatement gives little guidance as to what may qualify: "Generally, the case is one in which the recitation of the facts to an average member of the community would arouse his resentment against the actor, and lead him to exclaim, 'Outrageous!'"244 The official commentary adds that the tort applies only when "the conduct has been so outrageous in character, and so extreme in degree, as to go beyond all possible bounds of decency, and to be regarded as atrocious, and utterly intolerable in a civilized community." 245 What is outrageous, then, is what the average member of the community would consider outrageous.

For a woman challenging street harassment, this standard can present insurmountable problems because sexist speech is so common in our society that the average member of the community probably regards harassment as an unavoidable, or even acceptable, part of life. As Jean Love has pointed out, this problem can be attributed at least in part to the application of a majoritarian test to a context in which the victim of discriminatory speech is a member of a minority or non-dominant group. ${ }^{246}$ If the average member of the community in fact regarded street harassment as outrageous and "utterly intolerable," such harassment simply would not exist.

Yet a third obstacle to tort claims based on intentional infliction of, emotional distress is posed by the requirement that the plaintiff show that she suffered extreme emotional distress, "so severe that no reasonable man could be expected to endure it. . . . [T] liability where the plaintiff has suffered exaggerated and unreasonable emotional distress . . ."247 The effects of street harassment include feelings of anger, disempowerment, fear, and emotional distress. ${ }^{248}$ Cheryl Branda, for example, did in fact suffer emotional upset accompanied by physical symptoms as a result of her harassment by Redd Foxx. ${ }^{249}$ Most women living in this society, however, have had to

242 See, e.g., Daniel Givelber, The Right to Minimum Social Decency and the Limits of Evenhandedness: Intentional Infliction of Emotional Distress by Outrageous Conduct, 82 COLUM. L. REV. 42, 46 (I982).

243 See, e.g., id. at 51-53; Jean C. Love, Discriminatory Speech and the Tort of Intentional Infliction of Emotional Distress, 47 WASH. \& LEE L. REV. I23, 147-49 (1990).

244 RESTATEMENT (SECOND) OF TORTS $\$ 46 \mathrm{cmt}$. d.

245 Id.

246 See Love, supra note 243 , at $148-49$.

247 Restatement (SECOND) OF TORTS $\$ 46 \mathrm{cmt}$. j.

248 See supra pp. 535-38.

249 See Branda v. Sanford, 637 P.2d I223, I225 (Nev. I98I). 
harden themselves to a steady dose of harassment in order to survive. They suffer, and go on with their lives. Under the standard for intentional infliction of emotional distress, the stoic victim is barred from recovery. 250

One exception exists to these stringent requirements for establishing intentional infliction of emotional distress, however: the special liability of common carriers or public utilities for certain insults by their agents. ${ }^{251}$ If there is a special relationship between the parties - such as common carrier and passenger or innkeeper and guest liability does not require proof that the insult was extreme and outrageous, but only that it was "gross."252 Early cases based this duty upon an implied contract. ${ }^{253}$ In the 1875 case involving the assault by a train conductor against a young schoolteacher, for example, the railroad was also held liable for damages for the insult and indignity she suffered. ${ }^{254}$ Her recovery in tort was based upon the railroad's breach of the contract of carriage, which was interpreted to include a duty to protect female passengers "against obscene conduct, lascivious behavior, and every immodest and libidinous approach."255 As the court stated: "Every woman has a right to assume that a passenger car is not a brothel; and that when she travels in it, she will meet nothing, see nothing, hear nothing, to wound her delicacy or insult her womanhood."256 Again, this rationale, based on nineteenth-century notions of women as chaste and delicate creatures, might appear out of place in the modern world, ${ }^{257}$ but translated into modern terms that instead reflect a respect for women's dignity and equality in access to public transportation, the tort addresses a modern problem with substantial impact on the lives of women. ${ }^{258}$

250 See Love, supra note 243 , at $157-58$.

251 See RESTATEMENT (SECOND) OF TORTS $\$ 48$ ("A common carrier or other public utility is subject to liability to patrons utilizing its facilities for gross insults which reasonably offend them, inflicted by the utility's servants while otherwise acting within the scope of their employment.").

252 Id. $\S 48 \mathrm{cmt}$. c; see also id. $\S 46 \mathrm{cmt}$. d (exempting from "outrageous conduct" requirement those situations in which there is a special relationship between the parties); id. $\S 48 \mathrm{cmt}$. c (explaining that for liability of public utilities to attach under $\S 48$, conduct need not be "extreme[ly] outrage[ous]," but only "merely insulting").

253 See id. $\$ 48 \mathrm{cmt}$. a.

254 Craker v. Chicago \& Northwestern Ry., 36 Wis. 657, 675 (1875); see supra pp. 527-28.

${ }^{255}$ Craker, 36 Wis. at 672 (quoting Nieto v. Clark, 18 F. Cas. 236, 238 (C.C.D. Mass. 1858) (No. 10,262)).

256 Id. at 674 .

257 See supra pp. 550-5I.

258 In discussions of harassment with female students and friends, many told gruesome stories of their experiences riding trains and buses to school and to work. One of my students described men who come up and "smell" women passengers. She also recounted hearing one man loudly proclaim to his companion, "I want me a piece of that." When the student looked up, expecting to see someone carrying a cake, she realized that they were pointing at and talking about her. 
The Wisconsin schoolteacher recovered $\$$ Iooo, a large amount in I875, as damages for her mental suffering, vexation, anxiety, fear, outraged feeling, insulted virtue, and mental humiliation. ${ }^{259}$ Perhaps most important, the railroad company was held vicariously liable for the actions of its employee, thus providing an incentive for it to select non-harassing employees and to monitor their activities once placed in a position that could be abused in this fashion. ${ }^{260}$

A common carrier's responsibility for protecting female passengers against harassment may even extend to situations in which the harasser is not an employee but rather a fellow passenger. Thus, in I92I a state court ordered a street railway company in St. Louis to pay $\$ 500$ in damages to a female passenger whom the conductor had failed to protect from harassment by another passenger. ${ }^{261}$ Here, of course, the railroad could not have protected itself from liability simply by hiring courteous employees, but was held responsible both to train and to require its employees to intervene in situations of harassment.

In short, if a woman is "lucky" enough to be harassed by an employee or patron of a common carrier or hotel while she is using their services, she may recover damages. Given the lack of attention directed to street harassment in the modern world, this is a basis of liability that should be made widely known to women. A few highly publicized harassment cases, even if they take place in buses or hotels, may raise public consciousness about this issue in general. ${ }^{262}$ Apart from the common carrier or hotel guest situation, however, the tort of intentional infliction of emotional distress as now interpreted is unlikely to provide an effective remedy for street harassment - at least until the public is educated to regard it as outrageous. ${ }^{263}$

\section{E. The Tort of Intrusion or Invasion of Privacy}

Women's stories typically depict the experience of street harassment as an invasion of privacy: "I feel like that person is forcing his way

Law professor Morrison Torrey also reports an incident in which a man exposed himself to her on a Chicago Transit Authority bus at Io:00 a.m. while she was on her way to work.

259 See Craker, 36 Wis. at 679.

${ }^{260} \mathrm{Cf}$. Ellison v. Brady, 924 F.2d 872, 882 (gth Cir. I99I) (holding that Title VII requires an employer to take greater remedial measures in response to an incident of employee sexual harassment than merely requesting that the perpetrator refrain from continuing it).

261 See Liljegren v. United Rys., 227 S.W. 925, 926 (Mo. Ct. App. I92I). The offending passenger, who was intoxicated, had grabbed the plaintiff and kissed her against her will. See id; see also Annotation, Civil Liability for Insulting or Abusive Language Not Amounting to Defamation, I5 A.L.R.2d 108, I44-49 (195 I) (listing cases concerning carrier liability for the use of indecent language by persons other than carrier employees).

262 The Clarence Thomas confirmation hearings had such an effect on public consciousness about workplace harassment.

${ }^{263}$ See supra p. 565. 
into my space, whether I like it or not"';264 "[m]y reaction . . . was rage that once again someone was shattering my peaceful hour alone outdoors."265 For this reason, I consider the potential of the tort that corresponds to this experience. The tort of invasion of privacy, which arises out of Warren and Brandeis's famous statement of "the right to be let alone," 266 includes as one subcategory the tort of intrusion:

One who intentionally intrudes, physically or otherwise, upon the solitude or seclusion of another or his private affairs or concerns, is subject to liability to the other for invasion of his privacy, if the intrusion would be highly offensive to a reasonable person. ${ }^{267}$

From this description alone, the invasion of privacy tort seems to be an ideal remedy for street harassment. The intent required is merely the intent to intrude, not to harass or to injure, and the intrusion need not be a physical one.

The official comments to section $65_{2} \mathrm{~B}$ of the Restatement (Second) of Torts, however, qualify any initial optimism. They state that "the interference with the plaintiff's seclusion [must be] a substantial one, of a kind that would be highly offensive to the ordinary reasonable man, as the result of conduct to which the reasonable man would strongly object."268 Here, again, we are confronted with the problems presented by the reasonable man standard. ${ }^{269}$ What if the reasonable man, judge, or jury does not regard insulting, gender-based epithets directed at a woman on the street as "highly offensive" or does not "object strongly" enough to trigger liability?

This was, in fact, the result in the only case I have located in which a woman who was the target of harassment chose to rest her case exclusively upon the right of privacy. She argued that "the right to be let alone is a natural one, protected by natural law, and hence deserving of a remedy."270 (This woman obviously had seen the connection between the right to be free of street harassment and the fundamental values implicated in liberal democratic thought.) $)^{271}$ Not so, held the court. The court acknowledged that there was a right of privacy in Pennsylvania, but held that the right did not extend to the

264 Kissling \& Kramarae, supra note 22, at 83 (quoting a participant in a discussion of street remarks that was conducted on a computer system).

265 Winegar, supra note 84 , at 186.

266 Samuel D. Warren \& Louis D. Brandeis, The Right to Privacy, 4 HaRv. L. REv. 193, 193 (1890).

267 RESTATEMENT (SECOND) OF TORTS § 652B (1977).

268 Id. $\& 652 \mathrm{~B}$ cmt. d.

${ }^{269}$ See supra pp. 553-54, 562.

270 Christie v. Greenleaf, $78 \mathrm{~Pa}$. D. \& C. I9I, I9I-92 (Phila. County Ct. I95I). The defendant in this case made the plaintiff "the butt of billingsgate, harsh names and insulting gestures." Id. at I9I.

271 See supra notes $\mathrm{II}-\mathrm{I} 7$ and accompanying text. 
sort of "bad manners" attributed to the defendant; rather, "[a] thick hide must take the place of legal protection."272 Again, we see that the reasonable man does not regard street harassment as offensive enough to merit the protection of the law. The remedy, instead, is for women simply to develop thicker skins than they have already been required to grow. Thus, a victim's stoicism, which prevents recovery for intentional infliction of emotional distress (and for fighting words), is suggested as the remedy for harassment under the doctrine of invasion of privacy.

Moreover, according to the Restatement, "[t]he defendant is subject to liability . . . only when he has intruded into a private place, or has otherwise invaded a private seclusion that the plaintiff has thrown about his person or affairs."273 As examples of such places, the official comment points to homes or their functional substitutes, such as hotel rooms. ${ }^{274}$ Hence, ironically, women may invoke the protection of this tort only if they retreat to the private sphere - the very areas that harassment teaches is their place.

In short, invasion of privacy has not offered an effective remedy for street harassment, both because such harassment takes place in public and because the "man of ordinary sensibilities" does not regard such conduct as highly offensive. There is nothing inherent in the definition of the tort, however, to prevent its application to this situation. It has been developed by the common law to address certain presently limited circumstances, and it is our challenge to expand its application to include situations that offend the "woman of ordinary sensibilities," such as street harassment.

\section{F. Self-help Remedies}

Any account of women's search for remedies for street harassment would be incomplete without a discussion of the extra-legal remedies that women have historically employed. In the absence of effective legal protection, women have developed a creative repertoire of selfhelp measures. I have discussed the common response of ignoring the harasser and taking internal sanctuary, aided by sunglasses, Walkmen, and frozen stares - and the toll this protective behavior takes on the women who adopt it. ${ }^{275}$ Such a shielding response also appears to provide little protection for women. Instead, a failure to respond usually leads to further criticism, taunts such as "What's the matter? Stuck up?,"276 and possibly physical attack. Additionally, a habit of

272 Christie, $78 \mathrm{~Pa} \mathrm{D}$. \& C. at 192.

273 Restatement (SECOND) OF TORTS $\$ 652 \mathrm{~B} \mathrm{cmt.} \mathrm{c} \mathrm{(r977).}$

$274 \mathrm{See}$ id. at $\S 652 \mathrm{~B} \mathrm{cmt}$. b.

275 See supra p. 537.

276 Gardner, supra note 20 , at 347 . 
nonresponse may condition women to be passive victims in the future. ${ }^{277}$ Moreover, many experts believe that harassers who are given passive and/or placating responses may feel free to repeat the cycle of harassment. ${ }^{278}$ Hence, ignoring the harassment may exacerbate the problem.

Talking back may also backfire. Responding to a harasser ratifies the exchange. ${ }^{279}$ It also usually escalates the conflict to a higher level of verbal abuse. ${ }^{280}$ One woman, for example, reported the following interchange with harassers in New York City:

So I tell them, "Look. You look like nice guys. But it's not nice to comment on me like I'm just part of the scenery. I'm here for my own purposes. Okay?" One answers, "You know you're just a piece of meat to me, bitch."281

In the I970s, feminists created a number of measures to confront street harassment. They suggested copying down company names and license numbers from trucks, reporting the harassing behavior to the company, and requesting that a letter be placed in the offender's personnel file. ${ }^{282}$ Additionally, they suggested handing out cards that explained: "Sir: Perhaps you are unaware that what you just did was insulting to me as a woman. Try to think of how you would feel if your daughter, wife, sister or other relative or friend were treated in this way."283 Some women published form letters to be sent to employers of harassers, ${ }^{284}$ and others organized campaigns to boycott goods and services of businesses whose employees called after women on the street, made obscene signs or sounds, or verbally annoyed, abused, or patronized them. 285 One drawback of many of these measures is that they are aimed only at persons who harass on the job and thus are ineffective against men who are either unemployed or harass women when they are not at work. ${ }^{286}$ Nonetheless, women

\footnotetext{
277 See, e.g., MEdEA \& Thompson, supra note 95, at 52.

278 See Dana, supra note 27, at C5; James E. Gruber \& Lars Bjorn, Women's Responses to Sexual Harassment: An Analysis of Sociocultural, Organizational, and Personal Resource Models, 67 Soc. ScI. Q. 814, 823 (I986).

279 See Gardner, supra note 20 , at 346.

${ }^{280}$ See id.; Dana, supra note 27 , at $\mathrm{C}_{5}$.

281 Kannapell, supra note 30 , at 37.

282 See Joan Goldman, Walk Down Any Street and Be a Prisoner of War, MAjoRITY REp., Aug. 22, 1974, at 5 .

${ }^{283}$ Id. The gentility of this message was somewhat qualified by the reverse side, which stated that "[t]his card has been chemically treated. In approximately 36 hours your prick will fall off." Id.

${ }^{284}$ See, e.g., MAJORITy REP., Sept. 4-17, 1976, at 6 (providing a form letter to be filled out and sent to employers).

285 See id.

286 See Elizabeth A. Kissling, Unwanted Attention, Women \& Language, Spring 1985, at
} $3,25$. 
have continued to pursue these and similar tactics with some success. 287

More recent self-help strategies have also concentrated on educational measures - speakouts, workshops, and demonstrations of confrontation techniques - some of which are held on street corners. ${ }^{288}$ The Coalition for a Hassle-Free Zone in Washington has suggested that the District of Columbia be declared a "hassle-free" zone, where women may walk without fear of verbal sexual harassment. ${ }^{289}$ Confrontation workshops in Washington teach women to look the harasser in the eye, stand up tall, state "That's harassment. Women don't like it. Stop it," and then walk away - but only after the woman has determined that such a confrontation would be safe. ${ }^{290}$

Women also have written magazine articles, newspaper columns, letters to the editor - even academic articles such as this one - in an attempt to transform social consciousness about this issue. Without denigrating any of these efforts, most of which will continue to be necessary even if a more effective legal remedy becomes available, one must note that, despite these private campaigns, street harassment has continued to grow in intensity and frequency. One must therefore question the efficacy of individual responses to this problem that do not invoke the force of the law.

\section{G. What Conclusions Can Be Drawn from Past Experience with the Law?}

None of the efforts I have examined has yet provided an effective remedy for street harassment. No legal category quite "fits" the ha-

287 In Chicago, for example, the administration of DePaul University intervened with a construction company after receiving complaints from female students about harassment by construction workers at the Lincoln Park campus. The workers were told that if they did not cease their harassing behavior, they would be terminated from the job. Interview with Robert Janis, Associate Vice President for Physical Plant, DePaul University (Nov. Ir, 1992). Another recent example was reported on local television news in Chicago on February 21, 1992. A woman summoned police to deal with harassers at a construction site and subsequently complained to the construction company, which responded by firing the harassing workers. See Building Bias, CHI. TRIB., Mar. I5, I992, § 6, at I. Cheris Kramarae describes a similar incident in Cambridge, England, where a 26 -year-old woman reported a workman on a city job who made kissing noises at her; the City Council responded by ordering workmen to stop harassing women if they wanted to keep their jobs. See Kramarae, supra note 4, at II8 n.2. Another fine idea is to insist upon the inclusion of a non-harassment clause as a condition in the construction contract itself, especially in contracts for public works, in which the agency employing the contractor is accountable to the public. See Andrew Morgan, The Silent Brickeries of Hope Street, THE INDEPENDENT, Sept. 8, I992, at I8.

288 See Dana, supra note 27 , at $\mathrm{C}_{5}$; Wendy Milello, Calendar - Rape Prevention, Wash. PosT, Sept. 9, I986, at Tr6.

${ }^{289}$ See Dana, supra note 27 , at $\mathrm{C}_{5}$; I. Rajeswary, Anti-Rape Week Will Target Verbal Abuse, WASH. PosT, Sept. 20, 1985, at $\mathrm{C}_{2}$.

${ }^{290}$ See Dana, supra note 27 , at $\mathrm{C}_{5}$; Milello, supra note 288 , at TI6. 
rassment experience, although many come close. Assault is ineffective, because it requires that the defendant act with intent to cause harmful or offensive contact, that the woman's apprehension be objectively reasonable, and, in many states, that the defendant possess a present capacity to inflict injury and engage in conduct including more than "mere words." Similarly, harassment statutes are ineffective because they are defined in terms of the harasser's intent, require a continuing course of conduct, and have not been interpreted by the judiciary to be applicable to street harassment. Fighting words statutes are ineffective because they are premised on male experience and provide a remedy only if the verbal content of the harassment would cause the "man of ordinary intelligence" or the "average addressee" to react violently. In addition, the case law on these criminal remedies suggests that they are likely to be enforced in a discriminatory fashion, and many of the cases are premised on archaic and puritanical stereotypes of women as delicate creatures who are worthy of protection only if chaste.

The civil law remedies that have been applied to street harassment have thus far proved similarly ineffective. The tort of intentional infliction of emotional distress does not provide an adequate remedy because it requires proof of intent to inflict harm, proof that the conduct was extreme and outrageous in the eyes of an average member of the community, and proof of severe injury to the plaintiff. The tort of intrusion does not work in the harassment situation either, at least under its current definition, because it requires that the intrusion be highly offensive to a "man of ordinary sensibility" and that it be an intrusion into a place normally considered private.

The only common law remedy that appears to "fit" the behavior typical of street harassment is the duty of parties in a special or contractual relationship to protect patrons from gross insults that cause the infliction of emotional distress. Although I have located few modern reported cases involving harassment on buses or subways, ${ }^{291}$ such harassment clearly continues to exist.

What are we to make of the fact that none of these traditional legal categories has provided an effective remedy for street harassment, even though each, at first glance, appeared to be a promising

\footnotetext{
291 Most cases concerning harassment on public transportation by employees (bus drivers in particular) are apparently brought as intra-agency complaints and result in discipline or dismissal of the employee rather than any sort of recovery for the target. Thus, the accounts that do exist appear in reports of arbitration, see, e.g., In re Colonial Sch. Dist., 96 Lab. Arb. Rep. (BNA) I122, Ir24-25 (1991) (upholding the suspension and transfer of a male schoolbus driver whom female student passengers accused of making improper advances), or in cases involving due process challenges to dismissals caused by harassment, see, e.g., Green v. Board of Sch. Comm'rs, 7I6 F.2d IIgr, II92-93 (7th Cir. 1983) (rejecting a due process challenge to the dismissal of a schoolbus driver for sexual harassment of children on his bus).
} 
vehicle for relief? First, this observation simply offers additional evidence that neither statutory nor case law has developed with the experience of women in mind. ${ }^{292}$ Second, there are several conclusions one may draw about the course women should pursue to address the problem of street harassment in the future. On the one hand, one might conclude that any legal action is hopeless. The common themes pervading every legal category I have discussed (for example, that harassment is actionable only if the harasser intended to injure or alarm the woman, or if the reasonable or ordinary man would be offended, or afraid, or feel intruded upon) may indicate a general resistance to addressing the harms of harassment - a resistance that will defeat whatever women propose in this respect, whether it is poured into old or new vessels. This conclusion might cause the reasonable woman, with plenty of other legal battles on her hands, either to do nothing or to confine her efforts to the private sphere and focus on self-help and educational measures.

Another, more hopeful conclusion that may be drawn from the history I have described is that the law has developed thus far largely without the participation of women, but that women's input can force the legal system to take account of our experience now. Women have made substantial gains in the last few decades in the fields of workplace harassment, sexual assault, and domestic violence; similar pressure may create remedies for street harassment. Where crimes or torts have developed relatively rigid definitional requirements over a long period of time, however, the nature of the common law system may create substantial resistance. For example, it would be necessary to overturn longstanding statutory and case law to hold that the intent of the harasser is irrelevant to criminal assault. The chances of success may be greater under legal categories with looser definitions, such as invasion of privacy or the prima facie tort. ${ }^{293}$ Alternatively, women

292 As Catharine MacKinnon has pointed out in the context of workplace harassment, a fundamental reason "for the legal system's lack of response to sexual harassment is the conceptual inadequacy of traditional legal theories to the social reality of men's sexual treatment of women. It is no accident that no recognized legal category has been applied with any regularity to the entire fact pattern of sexual harassment." MacKinnon, supra note 2, at $16 \mathrm{I}$; see also Book Note, An Unlady-Like Response to Legal Conceptions of Women, I05 HARV. L. Rev. 2104, 2107-09 (1992) (reviewing SUSAN FALUDI: BACKLASH: THE UNDECLARED WAR AGAINST AMERICAN WOMEN (I99I)) (describing ways in which the law of sexual harassment ignores the reality of women's experiences).

293 The "prima facie tort" may be the perfect vehicle for harassment claims. The elements of this tort are simply: (I) an intentional lawful act by the defendant; (2) an intent to cause injury to the plaintiff; (3) injury to the plaintiff; and (4) the absence of any justification or an insufficient justification for the defendant's act. See, e.g., Kiphart v. Community Fed. Sav. \& Loan Ass'n, 729 S.W.2d 510, 516 (Mo. App. 1987). My research has located no harassment claims that have ever been brought under this rubric, and precious few prima facie tort cases of any sort. 
could design new statutory remedies specifically aimed at the typical harassment situation.

Based on the substantial victories women have already won, I believe that women should pursue both of these routes: to claim the legal remedies or "near-remedies" that exist, reforming them to fit the harassment experience, and to design new remedies when necessary, while continuing to fight a multi-front battle in the private sphere as well.

\section{TOWARd AN EFFective REMEdy FOR GeNDER-BASED STREET HARASSMENT}

Before designing any new remedies or reforming the ones that exist, it is important to review precisely what such measures should accomplish. The broadest goal, of course, is to change the behavior of harassers. Thus, the aim of any legal action should be the general deterrence of harassing behavior by means of realistic and effective remedies. Based upon the lessons drawn from previous efforts to fit harassment into existing legal categories, I conclude that such a remedy must:

(I) not define the offense or liability in terms of the intent of the harasser;

(2) incorporate a reasonable woman standard both as to the offensiveness of the conduct and the reasonableness of the woman's reaction to it;

(3) apply to both verbal and non-verbal conduct;

(4) not require repetition or a course of conduct;

(5) apply to behavior in public places but be limited to speech that is not public discourse;

(6) specify, if possible, that it applies to street harassment, so that the judiciary may not opt out of applying it to this situation;

(7) be worth the trouble and expense to pursue, either because it is "cheap" for victims to employ (for example, involving a simple procedure and/or free attorney), or because it has the potential for a substantial damage recovery; and

(8) "hurt" enough to provide general deterrence.

Finally, the goal of any such remedy must be the development of a legal category that corresponds to women's experience of harassment.

I recommend two ways in which these goals might be pursued: (I) the passage of statutes or ordinances specifically directed at street harassment, and (2) a litigation campaign aimed both at redefining the torts of assault, intentional infliction of emotional distress, and invasion of privacy to encompass street harassment and at publicizing and taking advantage of the variety of legal measures that are already available. 


\section{A. Passage of a State Statute or Municipal Ordinance Prohibiting Street Harassment}

The easiest way to ensure that a remedy will meet the criteria I have spelled out is to draft and work toward the passage of state statutes or municipal ordinances that specifically prohibit gender-based street harassment or to amend already existing harassment statutes to apply explicitly to street harassment. On the municipal level, it will be necessary to mount campaigns in many localities in order to achieve more general coverage, but given the distribution of both the problem and the population, it would make a big difference in the lives of large numbers of women if street harassment were eradicated in the largest cities. This type of local action also has the advantage of encouraging widespread participation and heightening attention to the problem. ${ }^{294}$ Moreover, a campaign to press for a new legal category embodied in an ordinance or statute would educate the public and organize women, even if it does not ultimately succeed. Finally, a criminal prohibition would define street harassment as an offense against the community as a whole, rather than as private or individual in nature, and would provide women the simple and immediate remedy of "calling the cops." 295

Such a statute or ordinance might read as follows:

Street harassment: It shall be a misdemeanor, punishable by a fine of $\$ 250$, to engage in street harassment. Street harassment occurs when one or more unfamiliar men accost one or more women in a public place, on one or more occasions, and intrude or attempt to intrude upon the woman's attention in a manner that is unwelcome to the woman, with language or action that is explicitly or implicitly sexual. Such language includes, but is not limited to, references to male or female genitalia or to female body parts or to sexual activities, solicitation of sex, or reference by word or action to the target of the harassment as the object of sexual desire, or similar words that by their very utterance inflict injury or naturally tend to provoke violent resentment, even if the woman did not herself react with violence. The harasser's intent, except his intent to say the words or engage in the conduct, is not an element of this offense. This section does not apply to any peaceable activity intended to express political views or provide public information to others.

A woman's dress and prior sexual history are irrelevant to the issue whether the harassment was welcome or unwelcome to her.

${ }^{294}$ Cf. Stephanie A. Levin, Grassroots Voices: Local Action and National Military Policy, 40 BUFF. L. REv. 32I, 332-34, 367-68 (1992) (proposing a "participatory federalism," which would enrich our constitutional values by stimulating grassroots voices that speak to national security concerns).

295 Of course, one must be concerned about the potential for discriminatory enforcement on the basis of race or class. See supra pp. $548 \&$ n.159, 551, 556. 
A "public place" is any place to which the public generally has access, including but not limited to streets, sidewalks, alleys, public buildings, public accommodations such as hotels, theaters, taverns, and restaurants, and common carriers such as trains, buses, and taxis.

A person who engages in street harassment while operating a motor vehicle is subject to revocation or suspension of his license to operate a motor vehicle or his chauffeur's license.

Any person aggrieved under this statute shall have a private cause of action for damages. ${ }^{296}$ Punitive damages shall also be available without proof of actual damages.

This draft statute or ordinance, unlike the traditional causes of action discussed above, establishes a standard that focuses on the harasser's objective conduct rather than his intent or viewpoint or the reaction of the target, except to the extent that she must allege that the conduct was not welcome. It provides a list of certain types of presumptively harassing behavior, without confining the conduct to those remarks or behaviors, in order to help law enforcement personnel and judges "know it when they see it." The ordinance does not specify that the conduct must be intimidating or frightening, lest a woman who reacts instead with a healthy anger be deprived of a remedy. Finally, although the draft provides for punishment by a fine, I would suggest an alternative sentence for first offenders. For example, the judge might impose an obligation to attend an educational program perhaps a video - that focuses on the effects of street harassment and attempts to alter the behavior of harassers by evoking empathy with their targets. ${ }^{297}$ Requiring harassers to come to court and view the educational video should be onerous enough to provide an effective deterrent. The model for this disposition, of course, is the traffic, or safe driving, school used in many areas as an alternative punishment to educate minor traffic offenders and hopefully prevent future arrests. The analogy is a good one, because the purpose of a street harassment ordinance, like that of a traffic regulation, is to make the streets safer for all citizens.

Additionally, although I have included the language of the "other" branch of the Chaplinsky test for fighting words - "words which by their very utterance inflict injury" - in the text of the statute, it is likely that opponents will challenge the statute's constitutionality on the grounds that it does not fall within the traditional "incitement to

296 A private right of action for violations of the statute is provided in order to take account of the large amount of discretion in the hands of police, who may not be sympathetic to enforcement of the statute, and to provide an alternative forum in which the harasser would not be entitled to the panoply of protections available under the criminal law.

297 This would be similar to the alternative sentence meted out to traffic offenders upon a first moving violation in Chicago, who are often offered the choice of watching a movie about safe driving instead of paying a fine. 
violence" branch of the fighting words doctrine. The substitute phrasing I have provided, drawn from the language of Georgia's harassment statute, is the phrase "words which naturally tend to incite violent resentment." The challenge of any test-case litigation will be to present evidence concerning the reaction of the average or reasonable woman to street harassment, in order to show that violent resentment may not result in violence when a woman is the target of fighting words, although similarly offensive language would provoke a man to react violently and thus breach the peace.

The ordinance I have suggested is obviously subject to First Amendment challenge. Because it is both gender-based and contentbased in its description of the prohibited behavior and possibly "underbroad" in the conduct it prohibits, the statute may be invalid under R.A.V. ${ }^{298}$ This probability should not deter women from working to pass such ordinances, for the process of introducing legislation and campaigning for its passage would provoke public discussion and raise consciousness about the harms of street harassment, even if the ordinance were ultimately overturned. ${ }^{299}$

Alternatively, women might opt to work for the passage of standard, all-purpose fighting words statutes, explicitly specifying during the legislative campaign that street harassment is included among the evils the statutes are intended to address. This effort would include mounting a subsequent litigation campaign to establish case law applying the fighting words statutes to street harassment, even if women's typical responses to harassment are pacific rather than "fighting."

\section{B. A Litigation Campaign to Redefine the Torts of Assault, Intentional Infiction of Emotional Distress, and Invasion of Privacy to Encompass Street Harassment}

A second strategy, which should be pursued at the same time as a legislative campaign, is a litigation campaign aimed at expanding existing tort categories such as assault, intentional infliction of emotional distress, and invasion of privacy to include street harassment.

In some cases, harassment may in fact include an actual physical touching or language or gestures intended to make the targeted woman fear that such contact may be imminent. Assault is an appropriate claim in such cases, and targets of street harassment should pursue claims with the aim of establishing a reasonable woman standard by which to measure the impact of the harasser's conduct. Evidence of

298 See supra pp. 546-48.

299 Certainly the pornography ordinances introduced and defended by Catharine MacKinnon and Andrea Dworkin in Minneapolis and Indianapolis had this effect, even though the latter was overturned by the court in American Booksellers Ass'n v. Hudnut, 771 F.2d 323, 325 (7th Cir. 1985). 
the effects of harassment on women, the relationship of harassment to rape and to fear of rape, and the reasonableness and universality of this fear on the part of women could then be introduced. The goal would be to shift the focus away from the perspective of the defendant and to tell the story of harassment from the point of view of its target, describing the woman's fear and her resulting loss of liberty. An additional aim of litigation based on assault should be to establish that the sexual history, race, class, and general character of the woman who is harassed are all irrelevant to her claim. If these goals were accomplished, the tort of assault might be restored to its position as the antithesis of liberty.

Second, women should bring suit against harassers based on the tort of intentional infliction of emotional distress, with the aim of showing that street harassment is in fact outrageous and intolerable in civilized society. Because the Restatement (Second) of Torts states that liability for emotional distress may arise from conduct that is caused recklessly as well as intentionally, ${ }^{300}$ women litigants should be prepared to demonstrate that, despite the testimony of harassers that they did not intend to cause distress, this result was so foreseeable that the harassers either knew or should have known that emotional distress would result and that they acted in conscious disregard of this knowledge. Again, it will be essential that the plaintiff testify (along, perhaps, with expert witnesses) about her realistic fears and anxiety.

This litigation should also aim to redefine the image of emotional distress that underlies this tort. Women must testify about the anger, feelings of disempowerment, anxiety, fear, and avoidance caused by harassment on the street - as well as about the energy wasted each day by the average reasonable woman, who must decide where she may safely walk, how to walk, what to wear, and what expression to freeze upon her face. We must attempt to establish that all of these reactions, along with the immense sense of outrage that must be revived if it is not present, constitute emotional distress that is deserving of legal remedy, not just loss of sleep and therapy bills.

Third, women should also claim the tort of invasion of privacy as their own. A woman jogger, for example, should be entitled to protect the "solitude or seclusion" she has "thrown about her person or affairs"301 and to demonstrate the offensive nature of the intrusion caused by harassment. Again, the impact of this intrusion must be measured by the reactions of the reasonable woman, with her reasonable expectations and fears.

Finally, women should take advantage of the variety of legal remedies already available to them, and those remedies should be

300 See Restatement (SECOND) OF TORTS \& 46(I) (Ig65).

301 Id. $\S 652 \mathrm{~B} \& \mathrm{cmt}$. c. 
publicized. Women should hold common carriers to their duty to ensure that passengers are not subjected to insults from other passengers or employees. Women should file administrative complaints and, if necessary, sue metropolitan transit authorities when they are subjected to outrageous comments or passengers exposing themselves to them on the bus. Similarly, the innkeeper-guest relationship that governs the liability of restaurant or tavern owners to female guests can be the basis for liability under the tort of intentional infliction of emotional distress when women are harassed by employees in hotels, restaurants, or bars. ${ }^{302}$ Finally, women should educate themselves about the typically simple procedures for filing complaints against taxi drivers who make harassing comments to passengers - procedures that may result in the suspension or deprivation of the cabdriver's license. ${ }^{303}$

In sum, women should mount a concerted effort to make the historical legal categories work for us, as they would work if women's injuries were taken seriously. Although it may not seem worthwhile to hire an attorney and bring suit in an individual harassment case given the difficulty of establishing damages, a few well-publicized cases supported by women's organizations - or by a few angry women with the resources to do so - might well reduce the incidence of harassment in general. Publicity might also make men more sensitive to the effects of this conduct. More important, it may make them realize that harassment is no longer acceptable or cost-free.

Even if harassing conduct were not substantially reduced, the benefits of such a campaign could be important. Litigation and discussion of that litigation among women and in the media would have the effect of making women feel justified - and no longer alone in their reactions to harassment. It might also convince us that this behavior is not simply a part of life, which we must silently endure, but rather something that can be discussed, condemned, and possibly even changed.

\section{CONCLUSION}

When I began to work on this Article and to discuss it with students, acquaintances, friends, and colleagues, I discovered that

302 See id. $\S 48 \mathrm{cmt}$. a.

303 For example, the city of Chicago's rules regulating taxis state:

Public chauffeurs shall be courteous to passengers, prospective passengers and other drivers at all times. Chauffeurs shall not assault, threaten, abuse, insult, provoke, interfere with, use profane language or offensive gestures around, impede or obstruct any person in connection with the operation of their vehicles.

Chicago, Ill., Dep't of Consumer Servs., Public Vehicle Operations Div., Rules and Regulations for Public Chauffeurs, Rule 2IA (I986). 
women do not frequently talk about street harassment, not even with one another. Instead, we suppress our feelings about it and may even repress the experience itself. More than once, women describing harassment experiences - including several unusually egregious experiences that happened to them as young girls - said that they had never told anyone else about what had happened to them or that they "had just remembered" something that once happened to them. Repression of this sort does not seem surprising, because the experience of street harassment is so common that it often seems to be an inevitable part of life. If one must live with it on a daily basis, it doesn't merit thinking about. Yet whenever I have asked female students and friends about their experiences and their opinions, they have invariably been responsive, have talked eagerly, and have reacted with a sense of solidarity and anger. They seem hopeful when I suggest that there might be legal remedies to address their pain, but this hope is often accompanied by expressions of incredulity, reflecting disbelief that the legal system will pay any attention to the problem. ${ }^{304}$ This dialogue and this anger are healthy, and they are creative. As Robin West points out,

[W]e must give voice to the hurting self . . . even when that hurting self voices 'trivial' complaints; even when the hurting self is ambivalent toward the harm and even when (especially when) the hurting self is talking a language not heard in public discourse. Only by so doing will we ourselves become aware of the meaning of the suffering in our lives, and its contingency in our history. Only when we understand the contingency of that pain, will we be free to address it and change the conditions which cause it through legal tools. ${ }^{305}$

This Article is an attempt to continue and to expand that dialogue.

\footnotetext{
304 Ironically, male law students proved more likely to assume that "something" should and could - be done to remedy street harassment by legal means.

305 West, supra note 9, at 86.
} 